2018, volume 7, issue 3

Olszak, M., Roszkowska, S., \& Kowalska, I. (2018). The joint effect of borrower targeted macroprudential instruments and capital regulations on procyclicality of loan-loss provisions. Copernican Journal of Finance \& Accounting, 7(3), 29-53. http://dx.doi.org/10.12775/CJFA.2018.014

Makgorzata Olszak

University of Warsaw

SYLWIA RoszKowsKa*

University of Łódź

IWONA KOWALSKA***

University of Warsaw

\title{
THE JOINT EFFECT OF BORROWER TARGETED MACROPRUDENTIAL INSTRUMENTS AND CAPITAL REGULATIONS ON PROCYCLICALITY OF LOAN-LOSS PROVISIONS
}

Keywords: macroprudential policy, loan-loss provisions, business cycle, procyclicality, capital regulations.

J E L Classification: E32, G21, G28, G32.

Date of submission: December 18, 2018; date of acceptance: February 14, 2019.

* Contact information: molszak@wz.uw.edu.pl, Faculty of Management, University of Warsaw, Szturmowa 1/3, 02-678 Warszawa, Poland, phone +48 22553 41 50; ORCID ID: https://orcid.org/0000-0001-8920-5309.

** Contact information: sylwiaroszkowska@gmail.com, Department of Macroeconomics, Faculty of Economics and Sociology, University of Łódź, Polskiej Organizacji Wojskowej 3/5, 90-255 Łódź, Poland; ORCID ID: https://orcid.org/0000-0002-60438210.

*** Contact information: ikowalska@wz.uw.edu.pl, Faculty of Management, University of Warsaw, Szturmowa 1/3, 02-678 Warszawa, Poland; ORCID ID: https://orcid. org/0000-0002-1208-2790. 


\begin{abstract}
We analyze the effects of macroprudential policy and micro-prudential capital regulations on the procyclicality of loan-loss provisions, using individual bank information from over 65 countries. In this study we test whether the interaction between borrower targeted macroprudential policy instruments and restrictive micro-prudential capital regulations tends to adjust the countercyclical effect of borrower targeted instruments and capital regulations. To this end we apply the two-step GMM estimator with robust standards errors. Our analysis implies that merging restrictive borrower targeted instruments and capital regulations tends to weaken the countercyclical effect of borrower targeted macroprudential policy instruments and restrictive capital adequacy regulations. This effect depends on size, and is stronger in large banks.
\end{abstract}

\title{
INTRODUCTION
}

Economic and finance theories offer several explanations for procyclicality in banking, and procyclicality of loan-loss provisions (for a well-grounded review refer to Borio, Furfine \& Lowe, 2001). General idea behind those explanations is the phenomenon of excessive risk-taking in economic upturns, followed with excessive risk-avoidance during downturns (see e.g. Borio \& Zhu, 2012), which can be termed as inadequate risk-taking behaviour during business cycle or inappropriate responses by banks to changes in risk over time (Borio et al., 2001). Considering the background assumptions behind the decision-making process of economic agents, there are two theoretical streams, which offer such justifications. The first one covers the market failures theories of classical economics (see Bank of England, 2009), which state that incentive problems (e.g. moral hazard as a side effect of deposit-insurance), information frictions (e.g. adverse selection, risk-illusion) as well as co-ordination or "free-rider problems. All these failures result in inadequate risk-taking behaviour of banks during the economic cycle.

The other set of explanations embraces cognitive biases (see Kahnemann \& Tversky, 1974), deeply rooted in behavioural finance (Barberis \& Thaler, 2003). Several cognitive biases are of importance to procyclicality in banking, e.g. biases due to retrievability of instances, anchoring, excessive optimism (Barberis \& Thaler, 2003), wishfull-thinking, and conservatism (Baker \& Wugler, 2012, p. 287). These biases result in disasters myopia - the tendency to underestimate the likelihood of high-loss low-probability events (Slovic, Fischhoff \& Lichtenstein, 1977). In banking, disaster myopia is exhibited in keeping too little capital for loan-losses, and thus may bring about increased insolvency risk (Herring, 1999). 
Previous evidence on loan-loss provisions and their sensitivity to the business cycle shows that loan-loss provisions tend to be procyclical, because they increase in economic downturns and decrease in economic upturns (Laeven \& Majnoni, 2003; Bikker \& Metzemakers, 2005; Skała, 2015; Olszak, Pipień, Kowalska \& Roszkowska, 2017; Olszak, Kowalska \& Roszkowska, 2018, Skała \& Weil, 2018; Godlewski, Skała \& Weill, 2018). This procyclicality is however diversified (Bikker \& Metzemakers, 2005). Some studies focus on several countries around world (Laeven \& Majnoni, 2003; Bikker \& Metzemakers, 2005), whereas others consider gretar number of countries (such as European Union see e.g. Olszak et al., 2017; or over 60 countries around the world, see e.g. Olszak et al., 2018), and find empirical evidence of diversity in procyclicality of loan-loss provisions (henceforth LLP). These differences may be explained to some extent by regulatory, supervisory as well as investor protection and financial sector structure and development (see Olszak et al., 2017), as well as macroprudential policy (see Olszak et al., 2018). In this paper we ask about another factor in this diversity, that is the role of joint impact of macroprudential policy instruments and capital adequacy standards restrictiveness.

As for macroprudential policy and its effects on procyclicality of banking activity, the evidence is increasing, but is still very fragmented (see Claessens, Ghosh \& Mihet, 2014; Olszak et al., 2018). Some recent cross-country studies show that macroprudential instruments are effective in reducing the procyclicality of credit growth and leverage (i.e. the sensitivity of credit and leverage to the business cycle; see Lim et al., 2011), as well as being effective in taming credit growth, leverage and/or asset growth (Claessens et al., 2014; Cerutti, Claessens \& Laeven, 2015; Alper, Binici, Demiralp, Kara \& Ozlu, 2014; Vandenbussche, Vogel \& Detragiache, 2015). Olszak et al. (2018) show that macroprudential policy instruments are effective in reducing procyclicality of LLP.

The previous literature stresses the empirical significance of bank size for risk-taking and thus the resilience of the banking sector. Due to the fact that large banks receive implicit or explicit government protection, they invest in more risky assets (De Haan \& Poghosyan, 2012; Freixas, Loranth \& Morrison, 2007). Large banks could also be more vulnerable to general market movements than smaller ones, meaning that the link between bank size and systemic risk may be positive (Anderson \& Fraser, 2000; Haq \& Heaney, 2012). Thus in our study we also look at the joint impact of borrower restrictions and capital regulations on procyclicality of LLP in banks which differ in size. 
Generally in our study we are interested in whether the interaction between borrower targeted macroprudential policy instruments and restrictive micro-prudential capital regulations tends to adjust the countercyclical effect of borrower targeted instruments and capital regulations, if we take them into account separately. We focus only on one micro-prudential instrument, i.e. capital standards, due to the fact that this instrument has been found effective in taming procyclicality of LLP in the EU. Other instruments, such as e.g. activity restrictions, were not reducing procyclicality of LLP (see Olszak et al., 2017).

We analyze the effects of macroprudential policy instruments and microprudential capital regulations on the procyclicality of loan-loss provisions, using individual bank information from over 65 countries. To conduct our analysis we apply the 2-step robust GMM estimator (Blundell \& Bond, 2008).

The rest of the paper is organized as follows. Section 2 describes the data set applied and the methodology used to test our hypotheses. Section 3 includes analysis of our empirical results. Section 5 presents conclusions.

\section{THE RESEARCH METHODOLOGY AND THE COURSE OF THE RESEARCH PROCESS}

We use pooled cross-section and time series data of individual banks' balancesheet items and profit and loss accounts from over 65 EU countries and country-specific macroeconomic indicators for these countries, over a period from 2000 to 2011. However, due to data shortages, we include only 65 countries in the analysis of the interactions between macroprudential policy, capital regulations and business cycle. The balance-sheet and profit-and-loss account data are taken from unconsolidated and consolidated financials available in the Bankscope database, whereas the macroeconomic data were accessed from the World Bank and the IMF web pages. We shall run separate regression in consolidated data, because consolidation is a proxy for bank size and thus risk-taking, which potentially maybe increased in banks consolidating financial statements (see Freixas et al., 2007).

The baseline descriptive statistics and correlations of the bank-level data applied in our study are included in tables A1 and A2 in the Appendix. As can be seen from the tables median LLP is diversified across countries. The same is found for the business cycle, proxied with real GPD growth (GDPG). Correlation matrices in panel B in table A2 suggest that LLP is procyclical, because it is negatively associated with GDPG in both unconsolidated and consolidated data. 
As we are interested in the impact of macroprudential policy on the link between loan-loss provisions and the business cycle, we include indices designed by the IMF and presented in Claessens et al. (2014) and included in the paper by Cerutti et al. (2015). Our study focuses on the period of 2000-2011, because we do not want our results to be affected by post-crisis regulatory changes, whose effective implementation started around 2012. Therefore in constructing aggregated macroprudential policy instruments, we only look at those instruments which were applied across countries in the period of 2000-2011. Obviously instruments which affect the capacity of borrowers to take a loan (i.e. loan-to-value caps and debt-to-income ratio) were very frequent tools applied by regulators in the period behind the crisis (see Cerutti et al., 2015). BORROWER values range between 0 and 2, with higher values suggesting grater application of macroprudential policy instruments which restrict access to credit of borrowers, in particular real-estate lending. This index covers two instruments: loan-to-value cap ratios (LTV_CAP) and debt-to-income ratios (DTI). The values of this index per each country applied in our study are presented in table A1 in the Appendix. To conduct our analysis we need one measure of borrower per each country, thus using the dataset presented in Cerutti et al. (2015), we compute average measure of this index for the period of 2000-2011. We also test the impact of one individual micro-prudential policy instrument i.e. capital regulations restrictiveness index (denoted as CAPREG). This index has been constructed by Barth, Caprio and Levine (2013) and its values applied in our study are included in table A1 in the Appendix.

The variables chosen as possibly explanatory of LLP are variables traditionally used for testing the earnings-management and capital-management hypotheses (Liu \& Ryan, 2006; Fonseca \& Gonzalez, 2008) modified by the inclusion of business-cycle and other dummy variables (as in Laeven \& Majnoni, 2003; Bikker \& Metzemakers, 2005). We also include the first and second lag of the dependent variable in order to capture adjustment costs that constrain the complete adjustment of LLP to an equilibrium level (see Laeven \& Majnoni, 2003; Bikker \& Metzemakers, 2005; and Fonseca \& González, 2008; Olszak et al., 2018). The basic model reads as:

$$
\begin{aligned}
& \operatorname{LLP}_{\mathrm{i}, \mathrm{t}}=\alpha_{0}+\alpha_{1} \mathrm{LLP}_{\mathrm{i}, \mathrm{t}-1}+\alpha_{2} \operatorname{LLP}_{\mathrm{i}, \mathrm{t}-2}+\alpha_{3} \text { PROFITBPT }_{i, t}+\alpha_{45} \Delta L_{i, t}+\alpha_{56} \text { CAPR }_{i, t-1}+\alpha_{6} \text { size }_{i, t} \\
& +\alpha_{7} G D P G_{j, t}+\alpha_{8} \text { Unempl }_{j, t}+\vartheta_{i}+\varepsilon_{i, t}
\end{aligned}
$$


The dependent variable is the loan loss provision (LLP) of a bank divided by this bank's average total assets (TA). The subindices $i, j, t$ refer to the bank, the country and the year - respectively. The explanatory variables have been subdivided into:

(1) bank-specific variables, namely:

- earnings before LLP and taxes (PROFITBPT),

- loans-growth rate $(\Delta \mathrm{L})$,

- capital ratio measured as the share of capital in total assets (CAPR);

(2) macroeconomic variables like:

- real growth of Gross Domestic Product per capita (GDPG),

- unemployment rate (Unempl);

(3) other elements, ie.:

- $\vartheta_{\mathrm{i}, \mathrm{t}}$ are unobservable bank-specific effects that are not constant over time but vary across banks;

- $\varepsilon_{\mathrm{t}}$ is a white-noise error term.

Our dependent variable is the total net loan-loss provision, covering netspecific provisions and general provisions (as reported in the Bureau Van Dijk Bankscope database). We control for individual bank conditions by including bank-specific variables. All bank-specific variables (LLP, PROFITBPT and CAPR) are normalized by the bank total assets (average assets in the case of LLP and PROFITBPT) to mitigate potential estimation problems with heteroscedasticity. Equation (1) involves bank-specific variables that may be endogenous. Therefore, we apply an approach that involves instrumental variables, i.e the generalised method of moments (GMM) developed by Blundell and Bond (1998) with robust standard errors and Windmeijer's (2005) correction. As the consistency of the GMM estimator depends on the validity of the instruments, we consider two specification tests. The first is Hansen's J statistic for overidentifying restrictions, which tests the overall validity of the instruments tests (see Roodman, 2009). The second is the test verifying the hypothesis of absence of second-order serial correlation in the first difference residuals (m2). Such an approach gives us estimates of standard errors robust with respect to heteroscedasticity and autocorrelation in the dataset.

The relation between LLP and current-period earnings realizations (PROFITBTP) is applied to track the discretionary income smoothing by banks (Liu \& Ryan, 2006; Fonseca \& González, 2008; Bouvatier \& Lepetit, 2008; Bushman \& Williams, 2012; Ozili \& Outa, 2018; Ozili \& Thankom, 2018). The higher the positive coefficient on PROFIT the more discretionary income smoothing there 
is. The association between LLP and $\triangle \mathrm{L}$ is included to test the application of LLP to cover expected loss on loans (Laeven \& Majnoni, 2003; Bikker \& Metzemakers, 2005; Fonseca \& González, 2008, Olszak et al., 2018). Some papers find positive influence of real loan growth on LLP (Bikker \& Metzemakers, 2005; Fonseca \& González, 2008) implying that banks set aside provisions to cover risks which build up during economic booms. Other studies document a negative coefficient on $\Delta$ Loans (Laeven \& Majnoni, 2003) which implies the rejection of the hypothesis of prudent loan-loss provisioning behavior. Capital ratio (CAPR) is used to control for the possibility that banks may engage in capital management through loan-loss provisions. As previous evidence documents, the relationship between CAPR and LPP may be both negative (Bikker \& Metzemakers, 2005) and positive (Bouvatier \& Lepetit, 2008).

The relation between LLP and GDPG is our measure of procyclicality of LLP, and as such is the most interesting in our study. Following previous empirical research we expect that GDP is negatively related to LLP (Laeven \& Majnoni, 2003; Bikker \& Metzemakers, 2005; Bouvatier \& Lepetit, 2008; Fonseca \& González, 2008, Olszak et al., 2017, 2018). The stronger the negative coefficient of GDP, the more procyclicality there is. Positive relationship between LLP and GDP would suggest countercyclical provisions. We ask if both borrower targeted instruments and capital regulations reduce procyclicality of LLP or even if they render them countercyclical. We aim to find out what is their joint effect on procyclicality of LLP.

We include Unempl as additional an exogenous macroeconomic control variable and expect the respective regression coefficient to be positive, suggesting that LLP increase as more employees get made redundant (i.e. which happens in economic downswings) (see Bikker \& Metzemakers, 2005; Olszak et al., 2017; 2018). Such a relationship is consistent with the procyclicality of LLP.

To analyze the differences in sensitivity of LLP to GDPG across countries and the role of macroprudential policy instruments as well as capital regulations restrictiveness in this sensitivity, we estimate a regression, incorporating an interaction term between macroprudential policy assessed at a country level (and capital regulations) and the GDPG variable. This regression reads as follows:

$$
\begin{aligned}
& \operatorname{LLP}_{\mathrm{i}, \mathrm{t}}=\alpha_{0}+\alpha_{1} \operatorname{LLP}_{\mathrm{i}, \mathrm{t}-1}+\alpha_{2} \operatorname{LLP}_{\mathrm{i}, \mathrm{t}-2}+\alpha_{3} \text { PROFITBPT }_{i, t}+\alpha_{45} \text { LL }_{i, t}+\alpha_{56} \text { CAPR }_{i, t-1}+\alpha_{6} \text { size }_{i, t} \\
& +\alpha_{6} \text { size }_{i, t}+\alpha_{7} G D P G_{j, t}+\alpha_{8} U_{n e m p l}^{j, t}+\alpha_{9} G D P G_{j, t} * B_{O R R O W E R_{j}}+\alpha_{10} G D P G_{j, t} * C A P R E G_{j} \\
& +\alpha_{11} G D P G_{j, t} * \text { BORROWER } R_{j} * C A P R E G_{j}+\vartheta_{i}+\varepsilon_{i, t}
\end{aligned}
$$


Following previous research, we expect that regression coefficient on product term between GDPG and BORROWER, will be positive, thus implying countercyclical impact of macroprudential policy on the sensitivity of LLP to GDPG (see Olszak et al., 2018). Olszak et al. (2017) show that CAPREG reduces procyclicality of LLP in the EU. So potentially, we also envisage that the regression coefficient on interaction term between GDPG and CAPREG will be positive, showing that this micro-prudential policy instrument may be effective in taming procyclicality of LLP. As for the joint effect of BORROWER and CAPREG on sensitivity of LLP there is no previous evidence. Generally, positive coefficient on the triple interaction of BORROWER, CAPREG and GDPG would imply that in countries with stronger borrower targeted macroprudential instruments as well as with more restrictive capital regulation, the effectiveness of both policy measures in reducing procyclicality of LLP is increased. In contrast, a negative link between LLP and the triple interaction term, potentially suggests decreased effectiveness of BORROWER and of CAPREG in taming procyclicality of LLP.

\section{ESTIMATION RESULTS}

In table 1, we first present the effect of GDPG on LLP without inclusion of borrower targeted index and capital regulations restrictiveness index. Looking at baseline specifications (see columns 1 and 3) we find that LLP is procyclical because the regression coefficient on GDPG is negative and statistically significant at $1 \%$. In particular, looking at columns 1 and 3, we find that regression coefficients range between _- 0.06 and _0.071. Other estimations (i.e. in columns 2 and 4) give coefficients ranging between _- 0.111 and _- 0.114 . This procyclicality view is further supported with the regression coefficients of unempl, because the link between LLP and unemployment rate is positive and statistically significant in three regressions (i.e. 1, 3 and 4) out of four in Table 1. Such results are consistent with previous empirical evidence (see Laeven \& Majnoni, 2003; Bikker \& Metzemakers, 2005; Bouvatier \& Lepetit, 2008; Olszak et al., 2017; 2018).

The coefficients on bank-specific variables are largely as expected when significant. Specifically, in all specifications the coefficient on PROFITBPT is positive and statistically significant at $1 \%$. This supports the view that in a cross-country context banks tend to engage in discretionary income smoothing (Bushman \& Williams, 2012). The negative coefficients on loans growth imply that banks do not apply a prudent approach to management of expected 
loan-losses (see column 1). Generally, changes in total loans outstanding or in loan growth rate are related to changes in expected loan-losses. Banks which provision more when loan growth is stronger should be less prone to macroeconomic conditions (Laeven \& Majnoni, 2003; Bikker \& Metzemakers, 2005; Fonseca \& González, 2008). In our sample we find support for the view that banks set aside provisions to cover expected losses only for consolidated data (see column 4). The coefficient of capital ratio in both negative and positive (and statistically significant only in unconsolidated data) thus showing that the link between capital ratio and LLP may be ambiguous (see columns 1 and 2 in table 1). The positive and statistically significant coefficient of the previous year's capital ratio (CAPR) (see regression 1 in table 1), implies that banks in our sample could have applied capital management with (consistent with explanation and findings of Liu \& Ryan, 2006; Bouvatier \& Lepetit, 2008). Some authors, however, argue that if capital variation is more related to retained earnings than to loan loss reserves, than the capital management hypothesis is verified if the link between LLP and CAPR is negative (Bikker \& Metzemakers, 2005). In our study we do find support for this view only in the regression including macroprudential policy index and capital regulation index.

In regressions 2 and 4, in which we include BORROWER and CAPREG, the coefficient on GDPG informs about the sensitivity of LLP to business cycle in countries which do not apply both macroprudential policy and in which capital regulations are not restrictive. Consistent with previous evidence (see Olszak et al., 2018), we find the BORROWER reduces procyclicality of LLP, because the coefficient on interaction term between BORROWER and GDPG is positive and significant at $1 \%$ in both consolidated and unconsolidated data. Increased restrictiveness of micro-prudential capital adequacy regulations also reduces the procyclicality of LLP, and this reduction is statistically significant, but only in unconsolidated data. Comparing the effects of BORROWER and CAPREG we find that macroprudential policy instruments tend to decrease procyclicality of LLP to a greater extent. In the case of BORROWER in the unconsolidated data we find that the negative coefficient on GDPG of -0.11 is reduced to -0.008 $(=-0.114+0.106)$ (see column 2 in table 1$)$. As for the effect of restrictive capital regulations we find that procyclicality of LLP is declined only slightly by 0.008 and overall equals $-0.106(=-0.114+0.008)$ (see column 2 in table 1$)$.

Looking now at the joint effect of both BORROWER and CAPREG on the cyclicality of LLP, we find that the regression coefficient on triple interaction term of CAPREG * BORROWER * GDPG is negative (ranging between -0.013 
and -0.012 , in columns 2 and 4, respectively) and statistically significant. Such a result implies that merging restrictive borrower targeted instruments and capital regulations tends to weaken the countercyclical effect of BORROWER and CAPREG, applied separately. In particular, looking first at unconsolidated data, the overall reduction in procyclicality due to BORROWER equal to -0.008 (see previous paragraph) is weakened by -0.013 up to $-0.021(=-0.008-0.013)$. Such a result implies that more restrictive capital standards reduce countercyclical effects of borrower-targeted macroprudential policy. As for the CAPREG, the slight reduction in procyclicality of LLP due to CAPREG (see regression coefficient on double interaction term between CAPREG* GDPG), is wiped out in countries which also apply borrower-targeted macroprudential policy instruments. Comparing coefficients on double interaction of CAPREG*GDPG and on triple interaction of CAPREG*BORROWER*GDPG, which equal, respectively, 0.008 and -0.013 , we find that procyclicality of LLP is slightly increased (i.e. the link between LLP and GDPG is more negative) by $-0.005(=0.008-0.013)$. The implications for the consolidated data, are the same as for unconsolidated data.

Table 1. Baseline results for the full sample in uncosolidated and consolidated data

\begin{tabular}{|c|c|c|c|c|}
\hline & \multicolumn{2}{|c|}{ Unconsolidated } & \multicolumn{2}{|c|}{ Consolidated } \\
\hline & (1) & (2) & (3) & (4) \\
\hline $\operatorname{LLP}(-1)$ & $\begin{array}{l}0.640^{* * *} \\
(11.53)\end{array}$ & $\begin{array}{l}0.534^{* * * *} \\
(8.05)\end{array}$ & $\begin{array}{l}0.432 * * * \\
(5.72)\end{array}$ & $\begin{array}{l}0.354^{* * *} \\
(4.32)\end{array}$ \\
\hline $\operatorname{LLP}(-2)$ & $\begin{array}{l}0.136^{* * *} \\
(3.17)\end{array}$ & $\begin{array}{l}0.134^{* *} \\
(2.51)\end{array}$ & $\begin{array}{c}0.141^{*} \\
(1.94)\end{array}$ & $\begin{array}{l}0.176^{* *} \\
(2.18)\end{array}$ \\
\hline PROFITBPT & $\begin{array}{l}0.069 * * \\
(2.48)\end{array}$ & $\begin{array}{l}0.133^{* * * *} \\
(2.83)\end{array}$ & $\begin{array}{l}0.145^{* * * *} \\
(3.38)\end{array}$ & $\begin{array}{l}0.168^{* * *} \\
(3.81)\end{array}$ \\
\hline$\Delta \mathrm{L}$ & $\begin{array}{l}-0.008^{* * *} \\
(-7.69)\end{array}$ & $\begin{array}{l}-0.002 \\
(-1.57)\end{array}$ & $\begin{array}{c}0.001 \\
(1.47)\end{array}$ & $\begin{array}{c}0.001^{*} \\
(1.96)\end{array}$ \\
\hline CAPR & $\begin{array}{l}0.012^{* * *} \\
(2.25)\end{array}$ & $\begin{array}{l}-0.020 * * * \\
(-3.88)\end{array}$ & $\begin{array}{c}0.001 \\
(0.17)\end{array}$ & $\begin{array}{c}0.003 \\
(0.45)\end{array}$ \\
\hline size & $\begin{array}{l}0.043^{* * *} \\
(9.23)\end{array}$ & $\begin{array}{l}-0.077^{* * *} \\
(-3.42)\end{array}$ & $\begin{array}{l}-0.011 \\
(-0.28)\end{array}$ & $\begin{array}{l}-0.028 \\
(-0.51)\end{array}$ \\
\hline GDPG & $\begin{array}{l}-0.060^{* * *} \\
(-16.11)\end{array}$ & $\begin{array}{l}-0.114^{* * *} \\
(-6.01)\end{array}$ & $\begin{array}{l}-0.071^{* * *} \\
(-10.71)\end{array}$ & $\begin{array}{l}-0.111 * * * \\
(-4.68)\end{array}$ \\
\hline unempl & $\begin{array}{l}0.017^{* * *} \\
(4.17)\end{array}$ & $\begin{array}{l}-0.001 \\
(-0.17)\end{array}$ & $\begin{array}{l}0.008^{* *} \\
(2.32)\end{array}$ & $\begin{array}{l}0.009 * * \\
(2.1)\end{array}$ \\
\hline BORROWER & & $\begin{array}{l}-0.311^{*} \\
(-1.91)\end{array}$ & & $\begin{array}{l}-0.291^{* * *} \\
(-2.76)\end{array}$ \\
\hline
\end{tabular}


Table 1. Baseline results for the full sample...

\begin{tabular}{|c|c|c|c|c|}
\hline & \multicolumn{2}{|c|}{ Unconsolidated } & \multicolumn{2}{|c|}{ Consolidated } \\
\hline & (1) & (2) & (3) & (4) \\
\hline BORROWER* GDPG & & $\begin{array}{l}0.106^{* * *} \\
(4.95)\end{array}$ & & $\begin{array}{l}0.094^{* * *} \\
(3.95)\end{array}$ \\
\hline CAPREG & & $\begin{array}{l}-0.048^{* * *} \\
(-4.18)\end{array}$ & & $\begin{array}{l}-0.014 \\
(-0.85)\end{array}$ \\
\hline CAPREG * GDPG & & $\begin{array}{l}0.008^{* * *} \\
(2.96)\end{array}$ & & $\begin{array}{c}0.005 \\
(1.23)\end{array}$ \\
\hline BORROWER* CAPREG & & $\begin{array}{l}0.048^{* *} \\
(2.25)\end{array}$ & & $\begin{array}{l}0.037 * \\
(1.86)\end{array}$ \\
\hline CAPREG * BORROWER * GDPG & & $\begin{array}{l}-0.013^{* * *} \\
(-3.80)\end{array}$ & & $\begin{array}{l}-0.012^{* * *} \\
(-2.66)\end{array}$ \\
\hline Constant & $\begin{array}{l}-0.657^{* * *} \\
(-8.43)\end{array}$ & $\begin{array}{l}1.755^{* * *} \\
(3.85)\end{array}$ & $\begin{array}{c}0.204 \\
(0.61)\end{array}$ & $\begin{array}{l}0.365 \\
(0.81)\end{array}$ \\
\hline $\mathrm{p}$-Hansen & 0.00 & 0.000 & 0.99 & 1.00 \\
\hline $\mathrm{m} 2$ & -1.64 & -1.089 & -1.64 & -1.36 \\
\hline$p$-val & 0.10 & 0.276 & 0.10 & 0.17 \\
\hline \# Obs & 7427 & 12522 & 7427 & 6033 \\
\hline
\end{tabular}

Notes to table 1 . This table presents the coefficient estimates of LLP on bank-specific determinants, macroeconomic variables and macroprudential policy instruments. separately for unconsolidated and consolidated data. The bank-specific determinants include: PROFITBPT - profit before provisions and taxes over average assets; $\Delta \mathrm{L}$ - loans growth; CAPR - equity capital divided by total assets; size - logarithm of total assets; Macroeconomic variables include: GDPG - real GDP growth per capita; Unempl - annual unemployment rate; BORROWER - borrower restrictions; CAPREG - index measuring restrictiveness of capital regulations; Reported regressions are estimated with the dynamic two-step system-GMM estimator as proposed by Blundell-Bond (1998) with Windmeijer's (2005) finite-sample correction for the period of 2000-2011 for panel data with lagged dependent variable (up to two lags of dependent variable are included. T-statistics are given in parentheses. $* * *, * *$ or $*$ next to coefficients indicate that coefficients are significantly different from zero at the $1 \%$, $5 \%$, or $10 \%$ levels, respectively. \# - denotes the number of.

S o u r c e : authors' calculations.

Considering the fact that procyclicality of LLP depends on bank size, we include additional tests of our results presented in table 1. In particular, in Table 2, we run regressions modelled with equation (Eq. 2) in three subsamples of banks, which differ in size. In this table we present effects of double interactions (i.e. BORROWER*GDPD and CAPREG*GDPG) as well as triple interactions between BORROWER, CAPREG and GDP per capita in in large banks (specifications 1 and 4), medium banks (specifications 2 and 5) and small banks (speci- 
fications 3 and 6). Estimated positive and significant coefficients of double interactions on BORROWER*GDPG and stronger in the subsample of large banks (the coefficient +0.148 and 0.15 in unconsolidated and consolidated data, respectively) suggest that large banks benefit the most from increased resilience resulting from macroprudential approach. Such a result is consistent with previous evidence (see Olszak et al., 2018). From regression 1 (large banks), for instance, we infer that the impact of GDPG on loan-loss provision in countries applying more borrower targeted instruments is $-0.01(-0.158+0.148)$. In the medium banks' regression, the overall effect of GDPG on loan-loss provisions in countries applying macroprudential instruments reducing demand for lending and increasing banking sector resilience (e.g. by improving the quality of loans through lower PD and LGD ratios) (i.e. in which BORROWER is higher), is relatively less attenuated than in the large banks and equals $-0.007(-0.056+0.049)$.

Table 2. The effect of restrictiveness of capital regulations and borrower targeted macroprudential policy instruments on the procyclicality of loan loss provisions - the role of bank size

\begin{tabular}{|c|c|c|c|c|c|c|}
\hline & \multicolumn{3}{|c|}{ Unconsolidated } & \multicolumn{3}{|c|}{ Consolidated } \\
\hline & large & medium & small & large & medium & small \\
\hline & (1) & (2) & (3) & (4) & (5) & (6) \\
\hline $\operatorname{LLP}(-1)$ & $\begin{array}{l}0.467^{* * *} \\
(4.65)\end{array}$ & $\begin{array}{l}0.391^{* * *} \\
(7.31)\end{array}$ & $\begin{array}{l}0.419 * * * \\
(3.90)\end{array}$ & $\begin{array}{l}0.403^{* * *} \\
(9.11)\end{array}$ & $\begin{array}{l}0.215^{* *} \\
(2.17)\end{array}$ & $\begin{array}{l}0.468^{* * *} \\
(5.48)\end{array}$ \\
\hline $\operatorname{LLP}(-2)$ & $\begin{array}{l}0.186^{* * * *} \\
(3.36)\end{array}$ & $\begin{array}{l}0.069 * * \\
(2.24)\end{array}$ & $\begin{array}{l}0.250^{* * *} \\
(3.41)\end{array}$ & $\begin{array}{c}0.038 \\
(1.11)\end{array}$ & $\begin{array}{l}0.414^{* * *} \\
(3.19)\end{array}$ & $\begin{array}{c}0.067 \\
(0.91)\end{array}$ \\
\hline PROFITBPT & $\begin{array}{l}0.098^{* *} \\
(2.32)\end{array}$ & $\begin{array}{l}0.164^{* * * *} \\
(4.46)\end{array}$ & $\begin{array}{c}0.146 * \\
(1.82)\end{array}$ & $\begin{array}{l}0.156^{* * * *} \\
(3.32)\end{array}$ & $\begin{array}{l}0.271^{* * *} \\
(4.84)\end{array}$ & $\begin{array}{l}0.055^{* *} \\
(2.11)\end{array}$ \\
\hline$\Delta \mathrm{L}$ & $\begin{array}{l}-0.002^{* *} \\
(-2.07)\end{array}$ & $\begin{array}{l}-0.003^{*} \\
(-1.78)\end{array}$ & $\begin{array}{l}-0.000 \\
(-0.07)\end{array}$ & $\begin{array}{c}0.001 \\
(1.07)\end{array}$ & $\begin{array}{l}0.002^{*} \\
(1.81)\end{array}$ & $\begin{array}{c}0.001 \\
(1.51)\end{array}$ \\
\hline CAPR & $\begin{array}{l}0.006 \\
(0.67)\end{array}$ & $\begin{array}{l}-0.021 * * * \\
(-3.30)\end{array}$ & $\begin{array}{l}-0.020^{*} \\
(-1.85)\end{array}$ & $\begin{array}{c}0.014 \\
(1.16)\end{array}$ & $\begin{array}{l}-0.016 \\
(-1.27)\end{array}$ & $\begin{array}{l}0.005 \\
(0.77)\end{array}$ \\
\hline size & $\begin{array}{l}-0.042^{*} \\
(-1.72)\end{array}$ & $\begin{array}{l}-0.072^{* * *} \\
(-3.74)\end{array}$ & $\begin{array}{l}-0.190^{* * *} \\
(-3.15)\end{array}$ & $\begin{array}{l}-0.109 * \\
(-1.73)\end{array}$ & $\begin{array}{c}0.066 \\
(0.84)\end{array}$ & $\begin{array}{l}-0.058 \\
(-0.68)\end{array}$ \\
\hline GDPG & $\begin{array}{l}-0.158^{* * *} \\
(-5.69)\end{array}$ & $\begin{array}{l}-0.056^{*} \\
(-1.93)\end{array}$ & $\begin{array}{l}-0.181^{* * *} \\
(-2.63)\end{array}$ & $\begin{array}{l}-0.177^{* * *} \\
(-4.34)\end{array}$ & $\begin{array}{l}-0.072^{* * *} \\
(-2.64)\end{array}$ & $\begin{array}{l}-0.061 \\
(-1.46)\end{array}$ \\
\hline unempl & $\begin{array}{c}0.002 \\
(0.35)\end{array}$ & $\begin{array}{c}-0.002 \\
(-0.33)\end{array}$ & $\begin{array}{l}0.010 \\
(0.64)\end{array}$ & $\begin{array}{l}0.000 \\
(0.00)\end{array}$ & $\begin{array}{l}0.016^{*} \\
(1.79)\end{array}$ & $\begin{array}{l}-0.001 \\
(-0.11)\end{array}$ \\
\hline BORROWER & $\begin{array}{l}-0.348^{* * *} \\
(-2.68)\end{array}$ & $\begin{array}{l}-0.115 \\
(-0.60)\end{array}$ & $\begin{array}{l}-1.597^{* * *} \\
(-2.58)\end{array}$ & $\begin{array}{l}-0.422^{* * *} \\
(-3.02)\end{array}$ & $\begin{array}{c}-0.058 \\
(-0.44)\end{array}$ & $\begin{array}{c}-0.074 \\
(-0.25)\end{array}$ \\
\hline
\end{tabular}


Table 2. The effect of restrictiveness...

\begin{tabular}{|c|c|c|c|c|c|c|}
\hline & \multicolumn{3}{|c|}{ Unconsolidated } & \multicolumn{3}{|c|}{ Consolidated } \\
\hline & large & medium & small & large & medium & small \\
\hline & (1) & (2) & (3) & (4) & (5) & (6) \\
\hline $\begin{array}{l}\text { BORROWER* } \\
\text { GDPG }\end{array}$ & $\begin{array}{l}0.148^{* * *} \\
(6.01)\end{array}$ & $\begin{array}{l}0.049 * \\
(1.69)\end{array}$ & $\begin{array}{l}0.241^{* *} \\
(2.19)\end{array}$ & $\begin{array}{l}0.15^{* * *} \\
(4.09)\end{array}$ & $\begin{array}{l}\text { 0.045* } \\
(1.69)\end{array}$ & $\begin{array}{l}0.044 \\
(0.83)\end{array}$ \\
\hline CAPREG & $\begin{array}{l}-0.034^{* *} \\
(-2.05)\end{array}$ & $\begin{array}{l}-0.029 \\
(-1.45)\end{array}$ & $\begin{array}{l}-0.137^{* * *} \\
(-2.95)\end{array}$ & $\begin{array}{l}-0.025 \\
(-1.11)\end{array}$ & $\begin{array}{l}0.019 \\
(0.82)\end{array}$ & $\begin{array}{l}-0.022 \\
(-0.64)\end{array}$ \\
\hline $\begin{array}{l}\text { CAPREG * } \\
\text { GDPG }\end{array}$ & $\begin{array}{l}0.013^{* * *} \\
(2.96)\end{array}$ & $\begin{array}{l}-0.001 \\
(-0.14)\end{array}$ & $\begin{array}{c}0.011 \\
(1.12)\end{array}$ & $\begin{array}{l}0.012 * \\
(1.94)\end{array}$ & $\begin{array}{l}-0.002 \\
(-0.44)\end{array}$ & $\begin{array}{c}0.003 \\
(0.44)\end{array}$ \\
\hline $\begin{array}{l}\text { BORROWER* } \\
\text { CAPREG }\end{array}$ & $\begin{array}{c}0.034^{*} \\
(1.84)\end{array}$ & $\begin{array}{l}0.027 \\
(0.92)\end{array}$ & $\begin{array}{l}0.288^{* * *} \\
(2.67)\end{array}$ & $\begin{array}{l}0.038 \\
(1.64)\end{array}$ & $\begin{array}{l}-0.013 \\
(-0.53)\end{array}$ & $\begin{array}{l}0.045 \\
(0.95)\end{array}$ \\
\hline $\begin{array}{l}\text { CAPREG * } \\
\text { BORROWER * } \\
\text { GDPG }\end{array}$ & $\begin{array}{l}-0.017^{* * *} \\
(-4.17)\end{array}$ & $\begin{array}{l}-0.006 \\
(-1.09)\end{array}$ & $\begin{array}{l}-0.035 \\
(-1.59)\end{array}$ & $\begin{array}{l}-0.017 * * * \\
(-2.94)\end{array}$ & $\begin{array}{l}-0.002 \\
(-0.49)\end{array}$ & $\begin{array}{l}-0.015 \\
(-1.44)\end{array}$ \\
\hline Constant & $\begin{array}{l}1.057^{* *} \\
(2.09)\end{array}$ & $\begin{array}{l}1.592^{* * *} \\
(4.21)\end{array}$ & $\begin{array}{l}3.781^{* * *} \\
(3.51)\end{array}$ & $\begin{array}{l}1.174 * * \\
(2)\end{array}$ & $\begin{array}{l}-0.57 \\
(-0.9)\end{array}$ & $\begin{array}{c}0.734 \\
(1.16)\end{array}$ \\
\hline $\mathrm{p}$-Hansen & 1.000 & 0.902 & 1.000 & 1.00 & 1.00 & 1.00 \\
\hline $\mathrm{m} 2$ & -1.799 & -0.593 & -1.319 & -1.40 & -2.63 & 0.77 \\
\hline$p$-val & 0.072 & 0.553 & 0.187 & 0.16 & 0.01 & 0.44 \\
\hline Obs & 4869 & 5714 & 1939 & 2411 & 2213 & 1409 \\
\hline
\end{tabular}

Notes to table 2. Variables description as in the table 1. Large is a dummy variable equal to 1 if a bank belongs to the $30 \%$ corresponding to the largest banks; medium is a dummy variable equal to 1 if a bank belongs to the next $40 \%$ of banks; small is a dummy variable equal to 1 if a bank belongs to the last $30 \%$ of banks with the smallest assets. All regressions include country and year dummies and interactions between country and year dummies.

S o u r c e : authors' calculations.

As for the small banks sample we do not find a consistent effect of BORROWER on the link between GDPG and LLP, because the impact is significant in unconsolidated data, and not significant in consolidated data. As for restrictive capital regulations, our results support the view that it is only large banks that exhibit reduced procyclicality due to the application of more restrictive capital adequacy regulations. The regression coefficient on the interaction term between CAPREG and GDPG is positive and statistically significant (at 1\%) only in the sample of large bank and equals 0.017 in both unconsolidated and consolidated data. Thus we find support for the view that restrictive capital regulations were effective in diminishing procyclicality of LLP mostly in large banks. 
Looking now at the joint effect of both BORROWER and CAPREG on the cyclicality of LLP in banks differing in size, we obtain result similar to the one obtained for the full sample, and statistically significant only in the large banks subsample. The regression coefficient on triple interaction term of CAPREG * BORROWER * GDPG is negative (equals about -0.017 , in columns 1 and 4). Such a result implies that merging restrictive borrower targeted instruments and capital regulations tends to weaken the countercyclical effect of BORROWER and CAPREG, applied separately.

\section{CONCLUSIONS}

We analyze the effects of macroprudential policy instruments and micro-prudential capital regulations on the procyclicality of loan-loss provisions, using individual bank information from over 65 countries.

In this study we test whether the interaction between borrower targeted macroprudential policy instruments and restrictive micro-prudential capital regulations tends to adjust the countercyclical effect of borrower targeted instruments and capital regulations. To this end we apply the two-step GMM estimator with robust standards errors.

Our analysis implies that merging restrictive borrower targeted instruments and capital regulations tends to weaken the countercyclical effect of borrower targeted macroprudential policy instruments and restrictive capital adequacy regulations. This effect depends on size, and is stronger in large banks.

Our results are of importance for regulatory policy decision-makers. First, we show that borrower targeted macroprudential policy instruments are more effective in reducing procylicality of loan-loss provisions than micro-prudential capital adequacy standards. Thus regulatory policy aimed at taming procyclicality of the financial sector should essentially be more concentrated on implementation of macroprudential policy instruments. Second, more restrictive capital standards tend to weaken countercyclical effects of macroprudential policy, however this reduction is relatively mild. Therefore, our results imply that the loss of efficacy of macroprudential policy due to restrictive capital standards is not very high. Consequently, our results are in favour of the use of more restrictive capital adequacy regulations, as an additional instrument, along with borrower targeted macroprudential tools. 


\section{ACKNOWLEDGMENTS}

We gratefully acknowledge the financial support provided by the Polish National Scientific Centre (NCN), No. of decision DEC-2012/05/D/HS4/01356. This paper's findings, interpretations, and conclusions are entirely those of the authors and do not necessarily represent the views of institutions to which the authors are affiliated.

\section{U11 REFERENCES}

Alper, K., Binici, M., Demiralp, S., Kara, H., \& Ozlu, P. (2014). Reserve Requirements, Liquidity Risk, and Credit Growth. Working Paper, No. 14/24. Central Bank of the Republic of Turkey. http://www.econ.itu.edu.tr/documents/activity20142015/Reserve-10-10-14.pdf (accessed: 14.01.2019).

Anderson, R.C., \& Fraser, D.R. (2000). Corporate control, bank risk-taking and the health of banking industry. Journal of Banking \& Finance, 24(8), 1383-1398. http:// dx.doi.org/10.1016/S0378-4266(99)00088-6.

Baker, M., \& Wurgler, J. (2012). Behavioral Corporate Finance: A Current Survey. In G.M. Constantinides, M. Harris, R.M. Stulz (Eds.). Handbook of the Economics of Finance: Vol. 2. New York: Handbooks in Economics.

Bank of England (BoE) (2009). The role of macroprudencial policy, Discussion paper.

Barberis N., \& Thaler, R.H. (2003). A Survey of Behavioral Finance. NBER Working Paper, No. 9222. http://www.nber.org/papers/w9222 (accessed: 17.08.2015).

Barth, J.R, Caprio, G.Jr., \& Levine, R. (2013). Measure it, improve it. Bank Regulation and Supervision in 180 Countries from 1999 to 2011. Journal of Financial Economic Policy, 5(2), 111-219. http://dx.doi.org/10.1108/17576381311329661.

Bikker, J.A., \& Metzemakers, P. (2005). Bank provisioning behavior and procyclicality. Journal of International Financial Markets, Institutions and Money, 15, 141-157. http://dx.doi.org/10.1016/j.intfin.2004.03.004.

Blundell, R., \& Bond, S. (1998). Initial conditions and moment restrictions in dynamic panel data model. Journal of Econometrics, 87(1), 115-143. http://dx.doi. org/10.1016/S0304-4076(98)00009-8.

Borio, C., Furfine, C., \& Lowe, P. (2001). Procyclicality of the financial system and financial stability: issues and policy options. BIS Papers, No. 1. Bank for International Settlements. http://www.bis.org/publ/bppdf/bispap01a.pdf (accessed: 14.01.2019).

Borio, C., \& Zhu, V.H. (2012). Capital regulation, risk-taking, and monetary policy: a missing link in the transmission mechanism? Journal of Financial Stability, 8(4), 236-251. http://dx.doi.org/10.1016/j.jfs.2011.12.003.

Bouvatier, V., \& Lepetit, L., (2008). Banks' procyclical behavior: does provisioning matter? Journal of International Financial Markets, Institutions and Money, 18(5), 513-526. http://dx.doi.org/10.1016/j.intfin.2007.07.004. 
Bushman, R., \& Williams, C.D. (2012). Accounting discretion, loan-loss provisioning, and discipline of banks' risk-taking. Journal of Accounting and Economics, 54(1), 1-18. http://dx.doi.org/10.1016/j.jacceco.2012.04.002.

Cerutti, E., Claessens, S., \& Laeven, L. (2015). The Use and Effectiveness of Macroprudential Policies: New Evidence. IMF Working Paper, WP/15/61. http://www.imf.org/ external/pubs/ft/wp/2015/wp1561.pdf (accessed: 14.01.2019).

Claessens, S., Ghosh, S., \& Mihet, R. (2013). Macro-Prudential Policies to Mitigate Financial System Vulnerabilities. Journal of International Money and Finance, 39, 153-185, http://dx.doi.org/10.1016/j.jimonfin.2013.06.023.

Claessens, S. (2014). An Overview of Macroprudential Policy Tools. IMF Working Paper, WP/14/214. https://www.imf.org/external/pubs/ft/wp/2014/wp14214.pdf (accessed: 14.01.2019).

Claessens, S., Ghosh, S.R., \& Mihet, R. (2014). Macro-Prudential Policies to Mitigate Financial System Vulnerabilities. IMF Working Paper, WP/14/155. http://www.imf. org/external/pubs/ft/wp/2014/wp14155.pdf (accessed: 14.01.2019).

De Haan, J., \& Poghosyan, T. (2012). Bank size, market concentration and bank earnings volatility in the US. Journal of International Financial Markets, Institutions and Money, 22(1), 35-54. http://dx.doi.org/10.1016/j.intfin.2011.07.002.

Fonseca, A.R., \& González, F. (2008). Cross-country determinants of bank income smoothing by managing loan-loss provisions. Journal of Banking \& Finance, 32(2), 217-228. http://dx.doi.org/10.1016/j.jbankfin.2007.02.012.

Freixas, X., Loranth, G., \& Morrison, A.D. (2007). Regulating financial conglomerates. Journal of Financial Intermediation, 16(4), 479-514. http://dx.doi.org/10.1016/j. jfi.2007.03.004.

Godlewski, C., Skała, D., \& Weill, L. (2018). Is Lending by Polish Cooperative Banks Procyclical? Working Papers of LaRGE Research Center, 2018-09. Laboratoire de Recherche en Gestion et Economie (LaRGE), Université de Strasbourg.

Herring, R. (1999). Credit risk and financial instability. Oxford Review of Economic Policy, 15(3), 63-79.

Kahneman, D., \& Tversky, A. (1974). Judgment under uncertainty: Heuristics and biases. Science, 185(4157), 1124-1131.

Laeven, L., \& Majnoni, G. (2003). Loan-loss provisioning and economic slowdowns: too much, too late? Journal of Financial Intermediation, 12(2), 178-197. http://dx.doi. org/10.1016/S1042-9573(03)00016-0.

Liu, Ch.-Ch., \& Ryan, G.S. (2006). Income Smoothing over the Business Cycle: Changes in Banks' Coordinated Management of Provisions for Loan Losses and Loan ChargeOffs from the Pre-1990 bust to the 1990s Boom. The Accounting Review, 81(2), 421-441. http://dx.doi.org/10.2308/accr.2006.81.2.421.

Olszak, M., Pipień, M., Kowalska, I., \& Roszkowska, S. (2017). What drives heterogeneity of cyclicality of loan-loss provisions in the EU? Journal of Financial Services Research, 51(1), 55-96. http://dx.doi.org/10.1007/s10693-015-0238-6.

Olszak, M., Kowalska, I., \& Roszkowska, S. (2018). Macroprudential policy instruments and procyclicality of loan-loss provisions - cross-country evidence. International 
Journal of Financial Institutions, Markets and Money, Elsevier, 54(C), 228-257. http:// dx.doi.org/10.1016/j.intfin.2018.01.001.

Ozili, P.K., \& Outa, E.R (2018). Bank Earnings Smoothing During Mandatory IFRS adoption in Nigeria, MPRA Paper, 89690. University Library of Munich, Germany.

Ozili, P.K., \& Thankom, A.G. (2018). Income smoothing among European systemic and non-systemic banks. The British Accounting Review, Elsevier, 50(5), 539-558. http:// dx.doi.org/10.1016/j.bar.2018.03.001.

Roodman, D. (2009). Practitioners Corner: A Note on the Theme of Too Many Instruments. Oxford Bulletin of Economics and Statistics, 71, 135-156. http://dx.doi. org/10.1111/j.1468-0084.2008.00542.x.

Skała, D. (2015). Saving on a Rainy Day? Income Smoothing and Procyclicality of LoanLoss Provisions in Central European Banks. International Finance, 18(1), 25-46. http://dx.doi.org/10.1111/1468-2362.12058.

Skała D., \& Weill, L. (2018). Does CEO gender matter for bank risk? Economic Systems, 42(1), 64-74. http://dx.doi.org/10.1016/j.ecosys.2017.08.005.

Slovic, P., Fischhoff, B., \& Lichtenstein, S. (1977). Preference for Insuring Against Probable Small Losses: Insurance Implications. Journal of Risk \& Insurance, 44(2), 237-258. http://dx.doi.org/10.2307/252136.

Vandenbussche, J., Vogel, U., \& Detragiache, E. (2015). Macroprudential Policies and Housing Prices: A New Database and Empirical Evidence for Central, Eastern, and Southeastern Europe. Journal of Money, Credit and Banking, 47(S1), 343-377. http:// dx.doi.org/10.1111/jmcb.12206. 


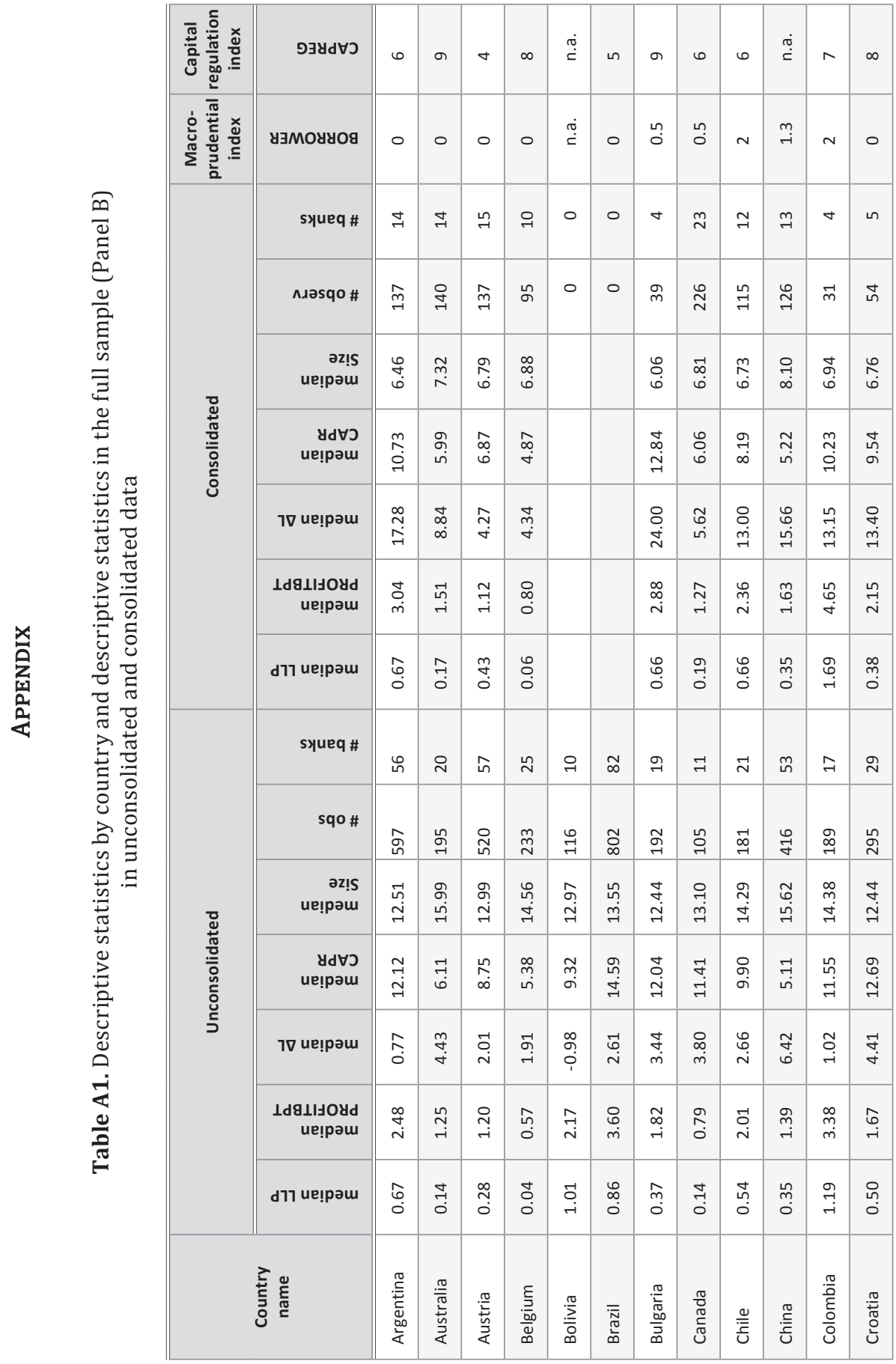




\begin{tabular}{|c|c|c|c|c|c|c|c|c|c|c|c|c|c|c|c|}
\hline 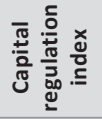 & פᄏyd כ כ & $\sigma$ & $\stackrel{\pi}{\check{C}}$ & 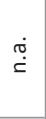 & $\sigma$ & 악 & $r$ & $\infty$ & 6 & $\infty$ & $\infty$ & $r$ & $n$ & 6 & $\theta$ \\
\hline 离 & уэмМучуо & $\hat{0}$ & 0 & 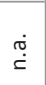 & $\stackrel{\infty}{\circ}$ & $\stackrel{\check{\pi}}{\check{c}}$ & 0 & 0 & $\circ$ & 0 & 0 & 0 & 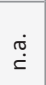 & $\sim$ & ָ̃. \\
\hline & syueq \# & $\nabla$ & 6 & $\stackrel{\sim}{\sim}$ & $\sim$ & 0 & 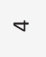 & $\nabla$ & $\sigma$ & $\stackrel{m}{m}$ & $\stackrel{\sim}{\sim}$ & $\nabla$ & $\stackrel{m}{\rightarrow}$ & $\vec{\lambda}$ & $\sigma$ \\
\hline & Аләsqo \# & mे & 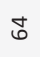 & 点 & $\approx$ & $\circ$ & $\stackrel{m}{m}$ & $\stackrel{\infty}{m}$ & $\stackrel{\infty}{m}$ & 岗 & $\stackrel{n}{\underset{\gamma}{\sim}}$ & \& & $\vec{m}$ & ন & $\widehat{\infty}$ \\
\hline & $\begin{array}{r}\text { әz!़ } \\
\text { ue!pəu }\end{array}$ & 赑 & $\stackrel{n}{\stackrel{n}{n}}$ & $\underset{\hat{\theta}}{-1}$ & $\underset{m}{m}$ & & $\underset{n}{\tilde{\omega}}$ & 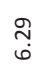 & 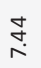 & 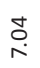 & $\begin{array}{l}n \\
\dot{\varphi} \\
\dot{0}\end{array}$ & 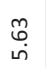 & $\stackrel{m}{r}$ & 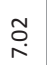 & 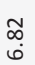 \\
\hline 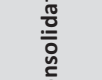 & $\begin{array}{r}\text { yd } \\
\text { ue!pəu }\end{array}$ & ఫ़ & $\begin{array}{l}\stackrel{L}{\circ} \\
\infty\end{array}$ & $\stackrel{m}{\stackrel{n}{b}}$ & $\begin{array}{l}\mathfrak{f} \\
\infty\end{array}$ & & $\begin{array}{l}0 \\
\infty \\
0 \\
0\end{array}$ & $\begin{array}{l}\stackrel{0}{\Lambda} \\
\infty\end{array}$ & i̊ & 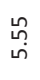 & 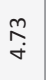 & $\underset{\stackrel{\sim}{H}}{\rightarrow}$ & $\stackrel{m}{n}$ & సू. & $\underset{\infty}{i}$ \\
\hline & $7 \nabla$ uе!рәши & $\stackrel{m}{a}$ & $\stackrel{n}{n}$ & $\begin{array}{l}\mathscr{8} \\
\infty \\
6\end{array}$ & 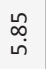 & & $\underset{m}{m} \underset{m}{m}$ & $\begin{array}{l}\stackrel{+}{m} \\
\stackrel{\sim}{\sim}\end{array}$ & ¿ & $\underset{\substack{\infty \\
+}}{\stackrel{+}{+}}$ & ने. & $\begin{array}{l}\hat{\sigma} \\
\dot{J}\end{array}$ & 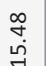 & જે & $\begin{array}{l}\text { o } \\
\dot{j}\end{array}$ \\
\hline & $\begin{array}{l}\text { Idglyoud } \\
\text { ue!pam }\end{array}$ & શ્ণ & $\begin{array}{l}\infty \\
\infty \\
\rightarrow\end{array}$ & 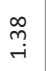 & $\begin{array}{l}\vec{b} \\
i\end{array}$ & & $\stackrel{\infty}{\stackrel{N}{i}}$ & $\underset{-}{\sigma}$ & कू & สิ & 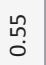 & $\stackrel{\infty}{\stackrel{\leftrightarrow}{\varphi}}$ & $\underset{f}{f}$ & $\stackrel{n}{\stackrel{n}{r}}$ & $\stackrel{\mathscr{n}}{\sim}$ \\
\hline & d77 ue!̣pəu & $\stackrel{n}{n}$ & 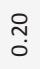 & $\underset{\substack{m \\
0}}{0}$ & fे & & $\stackrel{\infty}{\stackrel{\infty}{\rightarrow}}$ & $\underset{\substack{\text { m. } \\
0}}{0}$ & ¿̊ & $\stackrel{\infty}{-1}$ & ণ্ণি & $\underset{i}{\stackrel{i}{N}}$ & $\begin{array}{l}n \\
0 \\
0\end{array}$ & $\stackrel{m}{\dddot{m}}$ & ڤ̊ㅜㅇ \\
\hline \multirow{7}{*}{ 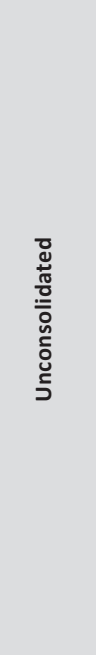 } & syueq \# & $r$ & $\stackrel{m}{\rightarrow}$ & ६ & $\grave{N}$ & $\approx$ & ㅇ & 0 & in & 点 & $\underset{\exists}{\rightarrow}$ & $\stackrel{\sim}{\sim}$ & $\stackrel{\sim}{\sim}$ & $n$ & 우 \\
\hline & sqo \# & $\mathscr{q}$ & ঃ & 옴 & $\stackrel{\mathscr{N}}{\sim}$ & 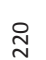 & ณ & हn & மீ & $\stackrel{n}{0}$ & 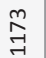 & लి & $\hat{m}$ & in & $\frac{2}{4}$ \\
\hline & $\begin{array}{r}\text { əz!S } \\
\text { ue!pəum }\end{array}$ & $\begin{array}{l}m \\
\stackrel{m}{r} \\
\dot{r}\end{array}$ & 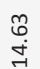 & $\underset{\tilde{m}}{\tilde{m}}$ & $\begin{array}{l}\stackrel{\circ}{0} \\
\stackrel{-}{\rightarrow}\end{array}$ & $\begin{array}{l}\stackrel{n}{m} \\
\stackrel{\sim}{\sim}\end{array}$ & $\begin{array}{l}\stackrel{\infty}{\infty} \\
\stackrel{\sim}{\exists}\end{array}$ & $\underset{\sim}{\stackrel{n}{\sim}}$ & $\hat{n}$ & $\begin{array}{l}\infty \\
\stackrel{\infty}{+} \\
\stackrel{+}{-1}\end{array}$ & 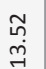 & 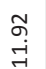 & 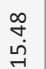 & $\begin{array}{l}\stackrel{P}{2} \\
\stackrel{\leftrightarrow}{n}\end{array}$ & 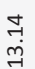 \\
\hline & $\begin{array}{r}\begin{array}{r}\text { yd } \\
\text { ue!poum }\end{array} \\
\text {. }\end{array}$ & 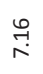 & $\stackrel{\bullet}{\circ}$ & 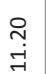 & $\begin{array}{l}\tilde{n} \\
\stackrel{-}{1}\end{array}$ & $\begin{array}{l}\hat{b} \\
\infty\end{array}$ & \begin{tabular}{l}
$\stackrel{+}{\infty}$ \\
0 \\
\hdashline
\end{tabular} & \begin{tabular}{l}
$m$ \\
$\infty$ \\
0 \\
\hdashline
\end{tabular} & $\begin{array}{c}\text { Ñ } \\
\text { in }\end{array}$ & $\stackrel{\infty}{\hat{\omega}}$ & $\stackrel{\text { L }}{r}$ & $\begin{array}{l}\infty \\
\infty \\
0 \\
9\end{array}$ & $\stackrel{0}{\stackrel{0}{\wedge}}$ & $\begin{array}{l}\infty \\
\infty \\
0 \\
0\end{array}$ & $\stackrel{m}{\stackrel{n}{\sigma}}$ \\
\hline & $7 \nabla$ ие!рәш & $\underset{f}{\stackrel{f}{+}}$ & \begin{tabular}{l}
0 \\
\multirow{1}{*}{} \\
$\infty$
\end{tabular} & $\begin{array}{l}\hat{\sigma} \\
\text { r }\end{array}$ & 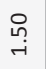 & $\begin{array}{c}\hat{m} \\
o \\
i\end{array}$ & $\begin{array}{l}\text { nू } \\
\text { ọ }\end{array}$ & $\underset{\leftrightarrow}{\mathscr{\sigma}}$ & मे & 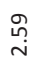 & $\stackrel{\sim}{\sim}$ & $\stackrel{+}{\circ}$ & 울 & $\stackrel{\infty}{\stackrel{\infty}{r}}$ & 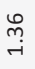 \\
\hline & $\begin{array}{r}\text { Idglyoyd } \\
\text { ue!paw }\end{array}$ & $\underset{i}{\stackrel{J}{i}}$ & $\underset{\sim}{\stackrel{T}{i}}$ & $\underset{H}{\mathscr{H}}$ & 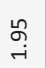 & ت্ & $\stackrel{\vec{n}}{\rightarrow}$ & $\stackrel{\infty}{+}$ & $\begin{array}{l}\stackrel{0}{\infty} \\
0 \\
0\end{array}$ & $\stackrel{m}{\sim}$ & $\stackrel{n}{\stackrel{n}{r}}$ & 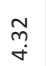 & $\underset{i}{\mathscr{r}}$ & 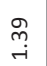 & 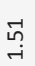 \\
\hline & d77 ue!̣рәш & $\underset{m}{n}$ & ने & 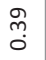 & $\begin{array}{l}\text { 足 } \\
\text { O }\end{array}$ & $\stackrel{\hat{\imath}}{o}$ & $\begin{array}{c}\infty \\
o \\
0\end{array}$ & $\stackrel{\stackrel{n}{*}}{\circ}$ & ơ & $\stackrel{-}{0}$ & $\stackrel{\infty}{\sim}$ & 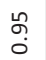 & $\stackrel{\infty}{+}$ & $\stackrel{m}{\sim}$ & ָั \\
\hline \multicolumn{2}{|c|}{ 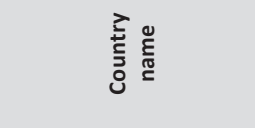 } & $\sum_{\substack{0 \\
0}}^{\frac{n}{2}}$ & 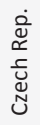 & 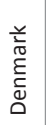 & 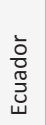 & 䓂 & $\begin{array}{l}\frac{\overline{0}}{0} \\
\frac{\pi}{\pi} \\
\frac{\pi}{\pi} \\
\frac{N}{\omega}\end{array}$ & 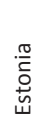 & 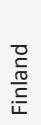 & 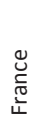 & 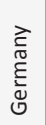 & $\begin{array}{l}\frac{\pi}{\pi} \\
\frac{\pi}{5}\end{array}$ & 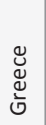 & 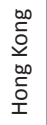 & 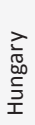 \\
\hline
\end{tabular}




\begin{tabular}{|c|c|c|c|c|c|c|c|c|c|c|c|c|c|c|c|}
\hline \multirow{9}{*}{ 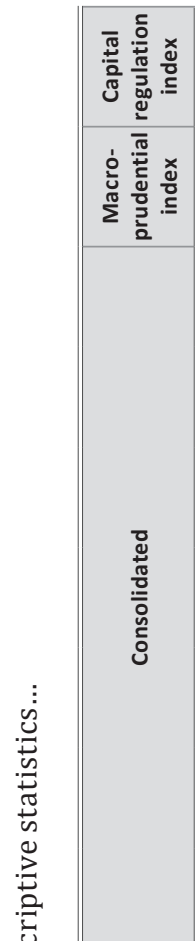 } & \multirow{2}{*}{ 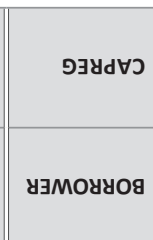 } & \multirow{2}{*}{$\begin{array}{l}0 \\
0\end{array}$} & \multirow{2}{*}{$\begin{array}{l}a \\
0\end{array}$} & \multirow{2}{*}{$\begin{array}{l}\text { 우 } \\
\circ\end{array}$} & \multirow{2}{*}{$\begin{array}{l}\infty \\
0\end{array}$} & \multirow{2}{*}{$\begin{array}{c}\infty \\
\stackrel{-1}{0}\end{array}$} & \multirow{2}{*}{$\begin{array}{l}0 \\
0\end{array}$} & & & & \multirow{2}{*}{$\begin{array}{l}\stackrel{\tilde{\Sigma}}{\check{\Sigma}} \\
0\end{array}$} & \multirow{2}{*}{$\begin{array}{l}\infty \\
0\end{array}$} & \multirow{2}{*}{$\begin{array}{l}a \\
\stackrel{0}{\circ}\end{array}$} & \multirow[b]{2}{*}{0} & \multirow{2}{*}{$\begin{array}{l}r \\
\text { 官 }\end{array}$} \\
\hline & & & & & & & & & & & & & & & \\
\hline & syueq \# & $m$ & $\exists$ & $\stackrel{m}{\rightarrow}$ & $\infty$ & 우 & 국 & in & 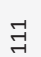 & $a$ & $r$ & $a$ & $\stackrel{m}{\rightarrow}$ & $\wedge$ & 6 \\
\hline & Аıәsqo \# & $\vec{\sim}$ & $\prod_{\infty}^{\infty}$ & $\stackrel{m}{\rightarrow}$ & $\stackrel{\circ}{\sim}$ & $\stackrel{\circ}{\exists}$ & $\hat{\sigma}$ & そ & $\stackrel{\circ}{\underset{I}{I}}$ & $\infty$ & $\approx$ & สั & $\stackrel{\infty}{\curvearrowleft}$ & ت & in \\
\hline & $\begin{array}{r}\text { әz!S } \\
\text { ue!pəuu }\end{array}$ & 匇 & $\underset{N}{N}$ & $\stackrel{-1}{\hat{\theta}}$ & $\stackrel{\stackrel{\infty}{n}}{\sim}$ & 穴 & $\stackrel{\hat{n}}{r}$ & $\begin{array}{l}\infty \\
\text { ô } \\
\text { in }\end{array}$ & $\stackrel{m}{\sim}$ & $\begin{array}{l}0 \\
\stackrel{7}{6}\end{array}$ & $\underset{n}{\tilde{\omega}}$ & $\stackrel{\hat{N}}{i}$ & कू & $\begin{array}{l}\circ \\
\stackrel{0}{0}\end{array}$ & $\stackrel{\infty}{\sim}$ \\
\hline & $\begin{array}{r}\text { yd } \\
\text { ue!pou }\end{array}$ & ñ & $\stackrel{\overbrace{}}{\emptyset}$ & $\stackrel{\mathscr{N}}{\sigma}$ & न्न & $\begin{array}{l}\vec{b} \\
\dot{i n}\end{array}$ & $\stackrel{n}{N}$ & 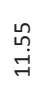 & $\underset{\sigma}{\stackrel{\sigma}{\sigma}}$ & 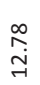 & $\begin{array}{l}0 \\
\stackrel{0}{0} \\
0\end{array}$ & 옥 & $\underset{\infty}{N}$ & $\begin{array}{l}\text { के } \\
\sigma\end{array}$ & $\underset{\text { શิ }}{\text { ம் }}$ \\
\hline & $7 \nabla$ uе!pәш & $\underset{\sim}{\tilde{m}}$ & $\stackrel{n}{\stackrel{n}{7}}$ & $\begin{array}{l}\vec{N} \\
\text { 岇 }\end{array}$ & 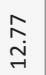 & $\stackrel{\infty}{\stackrel{\infty}{N}}$ & $\underset{\substack{m \\
\infty}}{\infty}$ & $\begin{array}{l}\text { ผn } \\
0 \\
0\end{array}$ & ڤ્ & $\underset{\mathfrak{N}}{\sim}$ & $\stackrel{\text { ֻ̊ }}{\text { in }}$ & $\stackrel{\vec{\infty}}{\wedge}$ & $\begin{array}{l}\vec{b} \\
\dot{\sim}\end{array}$ & $\begin{array}{l}\stackrel{\vartheta}{q} \\
\stackrel{\sim}{\oplus}\end{array}$ & $\underset{m}{\vec{m}}$ \\
\hline & $\begin{array}{l}\text { Idglyoyd } \\
\text { ue!pəum }\end{array}$ & 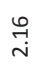 & $\stackrel{\sim}{\sim}$ & $\stackrel{0}{\stackrel{0}{i}}$ & $\underset{-}{8}$ & ને & $\underset{\sim}{\stackrel{d}{i}}$ & $\begin{array}{l}\varnothing \\
\dot{m}\end{array}$ & ְै & $\stackrel{\text { ֻ }}{\sim}$ & $\underset{m}{\stackrel{m}{+}}$ & $\begin{array}{l}\infty \\
\infty \\
m\end{array}$ & के & 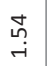 & ने \\
\hline & d77 ue!pəu & $\stackrel{0}{\text { ก }}$ & 音 & 冚 & $\stackrel{m}{?}$ & $\stackrel{\substack{\infty \\
\hdashline}}{0}$ & 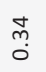 & $\begin{array}{l}0 \\
? \\
0\end{array}$ & m̊. & ษั. & $\stackrel{\sim}{\sim}$ & $\stackrel{n}{0}$ & ‡ั. & $\stackrel{m}{\stackrel{m}{0}}$ & రె. \\
\hline \multirow{7}{*}{ 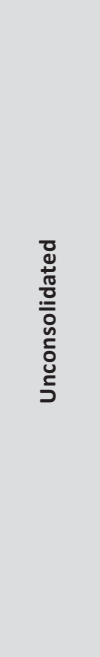 } & syueq \# & $r$ & फे & $\vec{\gamma}$ & $\sim$ & $\sigma$ & ঃ & 6 & 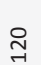 & $\sim$ & $\sigma$ & $\stackrel{\infty}{\sim}$ & ণ & 욱 & 6 \\
\hline & sqo \# & in & $\vec{J}$ & $\stackrel{\sim n}{m}$ & $\stackrel{m}{\rightarrow}$ & 官 & ô & ำ & 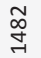 & $\stackrel{d}{\sim}$ & $\infty$ & $\stackrel{\overbrace{}}{\sim}$ & ని & $\underset{\exists}{\exists}$ & $\begin{array}{l}\infty \\
\text { in } \\
\text { n. }\end{array}$ \\
\hline & $\begin{array}{r}\text { əz!S } \\
\text { ue!pəuu }\end{array}$ & 先 & $\begin{array}{l}\stackrel{0}{+} \\
\text { î }\end{array}$ & $\underset{\sim}{\stackrel{f}{g}}$ & $\begin{array}{l}\infty \\
\stackrel{\infty}{\oplus} \\
\dot{\theta}\end{array}$ & $\begin{array}{l}\stackrel{0}{m} \\
\stackrel{\leftrightarrow}{\oplus}\end{array}$ & $\begin{array}{l}\stackrel{8}{\circ} \\
\stackrel{-}{+}\end{array}$ & $\begin{array}{l}\stackrel{0}{m} \\
\stackrel{\sim}{\sim}\end{array}$ & $\begin{array}{l}\overrightarrow{0} \\
\stackrel{\sigma}{0}\end{array}$ & $\begin{array}{l}\infty \\
\stackrel{\infty}{\sim} \\
\stackrel{\sim}{-1}\end{array}$ & $\underset{\substack{m \\
\text { i }}}{ }$ & $\stackrel{\infty}{\stackrel{\infty}{+}}$ & $\begin{array}{l}\stackrel{\infty}{6} \\
\underset{\sim}{\sim}\end{array}$ & 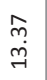 & 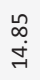 \\
\hline & $\begin{array}{r}\text { yd } \\
\text { ue!paum }\end{array}$ & 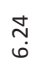 & $\begin{array}{l}\infty \\
\stackrel{\infty}{\infty} \\
\dot{\varphi}\end{array}$ & $\begin{array}{l}n_{0} \\
\stackrel{0}{0}\end{array}$ & $\begin{array}{l}\stackrel{n}{\stackrel{n}{+}} \\
\dot{\sigma}\end{array}$ & ?्? & $\underset{\infty}{\sim}$ & $\stackrel{\infty}{\stackrel{\infty}{-}}$ & $\stackrel{\mathscr{f}}{\stackrel{+}{+}}$ & $\begin{array}{l}\stackrel{\vdots}{\infty} \\
\sigma\end{array}$ & 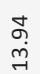 & 守 & $\stackrel{\mathscr{L}}{\sigma}$ & $\begin{array}{l}\stackrel{\mathscr{N}}{\sigma} \\
\sigma\end{array}$ & $\stackrel{f}{f}$ \\
\hline & $1 \nabla$ ue!pәш & مू & $\stackrel{\mathscr{N}}{\mathrm{N}}$ & ț & $\hat{o}$ & 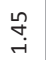 & $\stackrel{\hat{o}}{\dot{\gamma}}$ & न्7 & $\stackrel{\infty}{\sim}$ & $\underset{\text { ษ }}{-}$ & $\stackrel{\vec{m}}{\sim}$ & $\stackrel{\bullet}{0}$ & : & $\underset{f}{\stackrel{\varphi}{6}}$ & $\underset{i}{8}$ \\
\hline & $\begin{array}{r}\text { Idgllyoud } \\
\text { ue!pau }\end{array}$ & $\stackrel{\overbrace{}}{\mathrm{i}}$ & $\underset{\sim}{\stackrel{n}{-}}$ & $\stackrel{\infty}{\sim}$ & กี & कุ & $\stackrel{\infty}{\sim}$ & 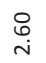 & $\stackrel{\substack{n \\
0}}{0}$ & क् & $\stackrel{\text { d }}{\text { i }}$ & $\underset{\sim}{\stackrel{D}{m}}$ & $\stackrel{n}{n}$ & $\underset{\rightarrow}{\stackrel{\sim}{r}}$ & $\stackrel{\infty}{\stackrel{\infty}{0}}$ \\
\hline & d77 ue!paw & $\stackrel{\infty}{m}$ & ปี & $\stackrel{+}{m}$ & $\begin{array}{l}\tilde{0} \\
\dot{0} \\
\dot{0}\end{array}$ & $\begin{array}{l}0 \\
m \\
0\end{array}$ & $\vec{m}$ & $\underset{\sim}{N}$ & $\vec{m}$ & $\stackrel{\substack{0 \\
0}}{0}$ & $\stackrel{\infty}{\infty}$ & $\underset{0}{\tilde{o}}$ & $\stackrel{\text { ָे }}{0}$ & $\stackrel{\substack{m \\
m \\
0}}{n}$ & $\stackrel{n}{0}$ \\
\hline \multicolumn{2}{|c|}{ 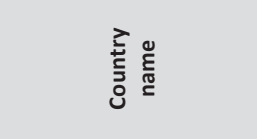 } & 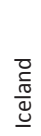 & 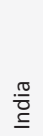 & 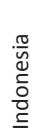 & $\begin{array}{l}\underline{0} \\
\underline{0} \\
\underline{0} \\
\underline{\underline{0}}\end{array}$ & $\begin{array}{l}\overline{\bar{\sigma}} \\
\underline{\tilde{\omega}}\end{array}$ & $\begin{array}{l}\frac{2}{\sqrt{0}} \\
\pm\end{array}$ & 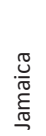 & $\begin{array}{l}\frac{\sqrt{0}}{0} \\
\frac{0}{\pi 0} \\
\frac{0}{10}\end{array}$ & $\begin{array}{l}\text { 등 } \\
\text { 임 }\end{array}$ & 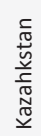 & 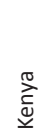 & 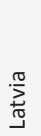 & 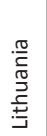 & 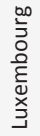 \\
\hline
\end{tabular}




\begin{tabular}{|c|c|c|c|c|c|c|c|c|c|c|c|c|c|c|c|}
\hline 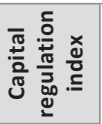 & 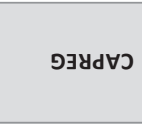 & 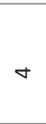 & r & $m$ & $\infty$ & $\infty$ & N & 6 & $n$ & $\infty$ & 6 & $\infty$ & $\infty$ & $\infty$ & $\sigma$ \\
\hline 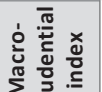 & УЭМОУУОЯ & $\rightarrow$ & 0 & 0 & 0 & 0 & 0 & $\stackrel{\check{d}}{\check{c}}$ & $\tilde{0}$ & $\stackrel{n}{\rightarrow}$ & $\stackrel{\pi}{\check{I}}$ & 0 & 0 & $\stackrel{-1}{0}$ & 0 \\
\hline \multirow{7}{*}{ 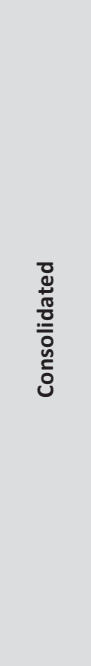 } & syueq \# & ન & $\sim$ & $\stackrel{\varphi}{\circ}$ & $\infty$ & ন & in & 욱 & n & $\exists$ & $\stackrel{0}{\sim}$ & $\nabla$ & $\stackrel{m}{\rightarrow}$ & $\sigma$ & $\sigma$ \\
\hline & ^ıəsqo \# & $\underset{\sim}{\infty}$ & N & ڤn & 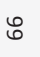 & $\stackrel{m}{\rightarrow}$ & f & $\infty$ & $\mathcal{\forall}$ & $\infty$ & $\stackrel{\stackrel{\sim}{\sim}}{\sim}$ & $\hat{m}$ & $\stackrel{\sim}{\rightarrow}$ & ने & $\infty$ \\
\hline & $\begin{array}{r}\text { әz!s } \\
\text { ue!pouा }\end{array}$ & $\stackrel{\overbrace{}}{N}$ & $\stackrel{\sim}{\leftrightarrow}$ & $\stackrel{-1}{\hat{\theta}}$ & ণ़ & $\stackrel{\text { L }}{r}$ & 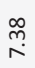 & 导 & $\stackrel{\circ}{\circ}$ & ঙ্ণ & $\begin{array}{l}\hat{\infty} \\
\hat{n} \\
i n\end{array}$ & ôn & นึ & مo & 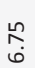 \\
\hline & $\begin{array}{r}\text { yd } \\
\text { ue!pau }\end{array}$ & 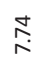 & 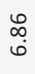 & 菅 & नै & น̊n & 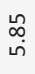 & $\begin{array}{l}\hat{6} \\
-i \\
-1\end{array}$ & 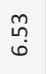 & $\stackrel{\infty}{\stackrel{\infty}{\sim}}$ & $\begin{array}{l}\tilde{1} \\
\infty \\
0 \\
0\end{array}$ & बें & $\underset{\sim}{\stackrel{\sim}{*}}$ & $\stackrel{\substack{m \\
\sigma}}{\sigma}$ & $\stackrel{\text { f }}{\sim}$ \\
\hline & $7 \nabla$ ие!рәш & 웅 & ने & 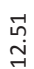 & 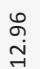 & $\underset{i}{\sim}$ & $\stackrel{\sim}{\infty}$ & ने & $\begin{array}{l}\infty \\
\infty \\
\infty\end{array}$ & के & $\begin{array}{l}\hat{\infty} \\
0 \\
0\end{array}$ & ஜ̊ & $\stackrel{\infty}{\sim}$ & 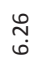 & $\begin{array}{l}\infty \\
\infty \\
\infty\end{array}$ \\
\hline & $\begin{array}{l}\text { Idg_lyoyd } \\
\text { ue!paw }\end{array}$ & $\underset{\text { i }}{\text { in }}$ & $\stackrel{\infty}{\stackrel{\infty}{-}}$ & $\stackrel{\substack{n \\
\text { N }}}{ }$ & $\stackrel{\text { \} }{\text { i }}} &{\underset{n}{\frac{m}{0}}} &{\text { 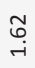 }} &{\begin{array}{l}\infty \\
\stackrel{\infty}{+}\end{array}} &{\begin{array}{l}\mathscr{\bullet} \\
\stackrel{0}{0}\end{array}} &{\stackrel{f}{i}} &{\stackrel{\infty}{\stackrel{\infty}{r}}} &{\underset{f}{f}} &{\text { ڤ̊ }} &{\stackrel{\infty}{\stackrel{\infty}{r}}} &{\underset{\sim}{-}} \\
{\hline} &{\text { d77 ue!pәш }} &{\text { 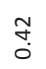 }} &{\text { : }} &{\text { م્ّ }} &{\stackrel{\text { ֻn }}{\circ}} &{\stackrel{7}{\stackrel{7}{0}}} &{\text { 웅 }} &{\text { 令 }} &{\stackrel{\circ}{0}} &{\stackrel{\circ}{\circ}} &{\text { f̊ }} &{\begin{array}{l}\overrightarrow{0} \\
0 \\
0\end{array}} &{\text { Fे }} &{\text { f̊ }} &{\text { 尚 }} \\
{\hline \multirow{7}{*}{\text { 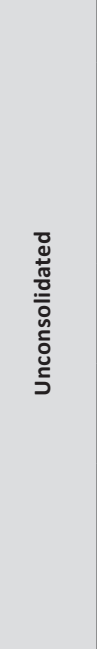 }}\text { 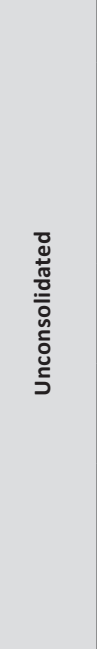 }} &{\text { syueq \# }} &{\stackrel{\sim}{\sim}} &{m} &{\text { N }} &{\wedge} &{\text { 우 }} &{\infty} &{9} &{\exists} &{\stackrel{\infty}{\sim}} &{\vec{m}} &{\exists} &{\stackrel{n}{\sim}} &{\stackrel{+}{m}} &{\underset{A}{A}} \\
{\hline} &{\text { sqo \# }} &{\underset{\sim}{\infty}} &{\text { 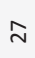 }} &{\stackrel{\circ}{\circ}} &{\stackrel{\infty}{\wedge}} &{\text { กิ }} &{\text { r }} &{\underset{\sim}{\infty}} &{\text { 의 }} &{\text { హ్ન }} &{\underset{\sim}{\infty} \underset{\sim}{\infty}} &{\text { ร }} &{\text { ને }} &{\stackrel{\infty}{\infty}} &{\underset{\Im}{\Im}} \\
{\hline} &{\begin{array}{r}\text { əz!S } \\
\text { ue!pəum }\end{array}} &{\text { 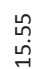 }} &{\text { 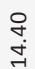 }} &{\text { 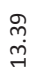 }} &{\stackrel{m}{m}} &{\begin{array}{l}\hat{b} \\
\dot{\sim}\end{array}} &{\begin{array}{l}\text { जે } \\
\text { فे }\end{array}} &{\begin{array}{l}\underset{\infty}{\infty} \\
\stackrel{\sim}{\rightarrow}\end{array}} &{\begin{array}{l}\vec{\infty} \\
\dot{\vec{J}}\end{array}} &{\begin{array}{l}\infty \\
\stackrel{\infty}{+} \\
\dot{\sim}\end{array}} &{\text { 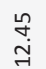 }} &{\text { 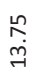 }} &{\begin{array}{l}8 \\
\dot{+} \\
\end{array}} &{\underset{\sim}{\stackrel{N}{r}}} &{\text { 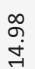 }} \\
{\hline} &{\begin{array}{r}\text { yd } \\
\text { ue!poum }\end{array}} &{\begin{array}{l}0 \\
\infty \\
\infty\end{array}} &{\stackrel{n}{\sim}} &{\text { 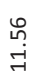 }} &{\underset{\infty}{\stackrel{d}{\infty}}} &{\underset{\infty}{\stackrel{d}{d}}} &{\underset{+}{\mathbb{i}}} &{\begin{array}{l}\stackrel{\llcorner}{\infty} \\
\underset{\exists}{\exists}\end{array}} &{\text { 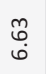 }} &{\stackrel{\infty}{\circ}} &{\text { 哭 }} &{\text { बे. }} &{\stackrel{m}{\underset{\sim}{ت}}} &{\text { 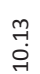 }} &{\begin{array}{l}\stackrel{0}{\hat{b}} \\
.\end{array}} \\
{\hline} &{7 \nabla \text { ue!pəum }} &{\stackrel{\text { H }}{\text { i }}} &{\underset{m}{\stackrel{J}{m}}} &{\stackrel{n}{n}} &{\text { 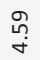 }} &{\stackrel{\sim}{m}} &{\stackrel{m}{\sim}} &{\underset{\sim}{\hat{m}}} &{\text { 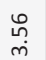 }} &{\hat{0}} &{\stackrel{+}{i}} &{\underset{m}{\dot{m}}} &{\text { ồ }} &{\stackrel{\substack{++}}{2}} &{\stackrel{d}{4}} \\
{\hline} &{\begin{array}{r}\text { Idgly-10yd } \\
\text { ue!̣paw }\end{array}} &{\text { 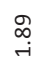 }} &{\text { 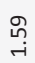 }} &{\stackrel{\overbrace{}}{\rightarrow}} &{\text { ì }} &{\underset{\sim}{\sim}} &{\stackrel{\mathscr{N}}{\sim}} &{\text { 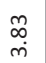 }} &{\begin{array}{l}\infty \\
\infty \\
0\end{array}} &{\underset{\sim}{\infty}} &{\underset{\sim}{\sigma}} &{\stackrel{\mathscr{n}}{\sim}} &{\text { 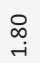 }} &{\text { 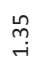 }} &{\stackrel{m}{\rightarrow}} \\
{\hline} &{\text { d77 ue!pәu }} &{\stackrel{\sim}{m}} &{\text { : }} &{\stackrel{\leftrightarrow}{\circ}} &{\text { 웅 }} &{\stackrel{\circ}{\circ}} &{\begin{array}{l}\infty \\
0 \\
0\end{array}} &{\stackrel{0}{5}} &{\stackrel{-}{-1}} &{\text { f̊ }} &{\text { Fे }} &{\underset{i}{\circ}} &{\text { กิ }} &{\vec{m}} &{\text { 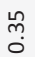 }} \\
{\hline} &{\text { 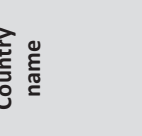 }} &{\begin{array}{l}\frac{\sqrt{0}}{\sqrt{n}} \\
\frac{\pi}{\pi} \\
\frac{\pi}{20}\end{array}} &{\frac{\frac{\pi}{0}}{\frac{\pi}{2}}} &{\begin{array}{l}\frac{8}{x} \\
\sum\end{array}} &{\text { 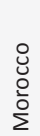 }} &{\begin{array}{l}\frac{n}{0} \\
\frac{1}{0} \\
\frac{\pi}{2} \\
\frac{1}{ \pm} \\
\frac{1}{2}\end{array}} &{\begin{array}{l}\frac{8}{2} \\
\frac{\pi}{\pi} \\
\frac{1}{10} \\
N \\
3 \\
\frac{0}{2}\end{array}} &{\text { 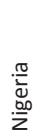 }} &{\begin{array}{l}\frac{\pi}{3} \\
3_{0}^{2} \\
z\end{array}} &{\text { 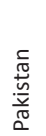 }} &{\text { 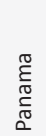 }} &{\frac{2}{2}} &{\text { 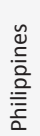 }} &{\begin{array}{l}\text { D } \\
\frac{\pi}{0} \\
\frac{0}{0}\end{array}} &{\text { 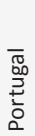 }} \\
$\hline
\end{tabular}


[50]

\begin{tabular}{|c|c|c|c|c|c|c|c|c|c|c|c|c|c|c|c|}
\hline 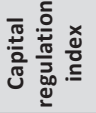 & פᄏyd כ כ & $\infty$ & $\wedge$ & $\infty$ & 6 & $\wedge$ & in & $a$ & $\infty$ & in & 芦 & s & $\wedge$ & $\sigma$ & 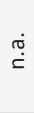 \\
\hline 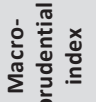 & уэмоучоя & -1 & 0 & -1 & -1 & $\circ$ & $\circ$ & $\stackrel{+}{\rightarrow}$ & -1 & 0 & ?. & 0 & $\stackrel{\pi}{\check{\Sigma}}$ & $\hat{0}$ & 0 \\
\hline \multirow{7}{*}{ 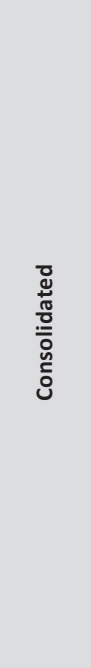 } & syueq \# & $n$ & En & in & 6 & $\infty$ & $\wedge$ & $\stackrel{m}{\rightarrow}$ & ฉి & $\infty$ & in & 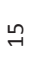 & 0 & $\exists$ & $\infty$ \\
\hline & ^גəsqo \# & in & $\stackrel{\leftrightarrow n}{\natural}$ & $\stackrel{\infty}{+}$ & î & $\infty$ & $\stackrel{\infty}{n}$ & $\stackrel{\sim}{\sim}$ & ᄋ్తి & $\infty$ & in & $\stackrel{\infty}{\sim}$ & 0 & $\stackrel{\infty}{\rightarrow}$ & i̊ \\
\hline & $\begin{array}{r}\text { әz!S } \\
\text { ue!pəuा }\end{array}$ & $\stackrel{\vec{~}}{\emptyset}$ & નુ & $\stackrel{\infty}{0}$ & $\begin{array}{l}\text { น̊ } \\
\text { h }\end{array}$ & $\stackrel{\substack{m \\
i}}{0}$ & $\stackrel{-1}{\stackrel{n}{r}}$ & $\stackrel{?}{\stackrel{2}{r}}$ & $\stackrel{-1}{r}$ & $\vec{~}$ & 국 & बू. & & $\stackrel{\text { ㄱ. }}{\pi}$ & $\begin{array}{l}\text { 7ั } \\
\text { ต }\end{array}$ \\
\hline & $\begin{array}{r}\text { yd } \\
\text { ue!poum }\end{array}$ & 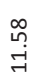 & 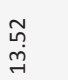 & $\begin{array}{l}\text { N } \\
\text { ت }\end{array}$ & $\underset{\infty}{\mathfrak{q}}$ & $\underset{\infty}{\stackrel{P}{\infty}}$ & $\underset{\sim}{\stackrel{8}{r}}$ & $\begin{array}{l}\text { ?े } \\
\text { in }\end{array}$ & 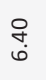 & $\begin{array}{l}\tilde{B} \\
\stackrel{0}{\varphi}\end{array}$ & $\underset{\sim}{\stackrel{\sim}{+}}$ & 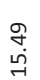 & & $\underset{\infty}{\stackrel{N}{N}}$ & $\begin{array}{r}\hat{\imath} \\
\sigma\end{array}$ \\
\hline & $7 \nabla$ uе!рәш & 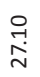 & I্ন & $\stackrel{\overrightarrow{n n}}{\dot{\sim}}$ & 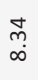 & $\begin{array}{l}\stackrel{\circ}{\circ} \\
\stackrel{-}{-1}\end{array}$ & خิ & $\begin{array}{l}n \\
\infty \\
\infty\end{array}$ & $\stackrel{\text { م }}{r}$ & $\begin{array}{l}\vec{f} \\
\text { in }\end{array}$ & $\begin{array}{l}\text { ô } \\
\text { gi }\end{array}$ & $\stackrel{\stackrel{n}{N}}{N}$ & & 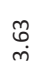 & $\begin{array}{l}\stackrel{0}{\infty} \\
\dot{\sim}\end{array}$ \\
\hline & $\begin{array}{r}\text { Idghlyoyd } \\
\text { ue!pəum }\end{array}$ & $\begin{array}{l}\text { Oे } \\
\text { in }\end{array}$ & $\stackrel{\stackrel{H}{n}}{m}$ & i & $\stackrel{m}{\text { ? }}$ & 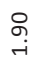 & $\underset{\sim}{\sim}$ & $\stackrel{n}{\stackrel{n}{i}}$ & $\underset{\sim}{\stackrel{\sim}{i}}$ & $\stackrel{f}{\text { i }}$ & $\begin{array}{l}? \\
0 \\
0\end{array}$ & $\underset{i}{\stackrel{i}{\sim}}$ & & : & $\stackrel{\text { L }}{\text { in }}$ \\
\hline & d77 ue!pəu & กิ & $\stackrel{\bullet}{\stackrel{-}{-}}$ & $\stackrel{7}{\stackrel{4}{0}}$ & $\underset{0}{\stackrel{T}{0}}$ & t. & $\begin{array}{l}\overrightarrow{1} \\
0 \\
0 \\
0\end{array}$ & $\begin{array}{l}\qquad 0 \\
0\end{array}$ & $\stackrel{\tilde{m}}{0}$ & 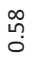 & : & न्: & & $\stackrel{\infty}{\leftrightarrow}$ & $\stackrel{\infty}{\rightarrow}$ \\
\hline \multirow{7}{*}{ 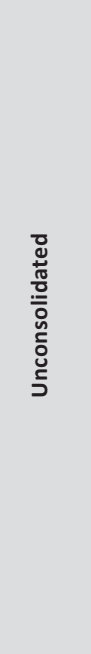 } & syueq \# & 9 & n & $r$ & $\sigma$ & ㄱ & 孛 & $\stackrel{\sim}{\sim}$ & $\hat{m}$ & ส & $\stackrel{1}{1}$ & $\underset{\exists}{\stackrel{9}{7}}$ & $\stackrel{\text { m }}{m}$ & $\stackrel{\infty}{\sim}$ & $\stackrel{\leftrightarrow}{\neg}$ \\
\hline & sqo \# & $\stackrel{ }{A}$ & ڤે & $\mathscr{8}$ & $\infty$ & $\underset{\exists}{\mathbb{Z}}$ & 总 & ర్తి & $\overrightarrow{\mathrm{m}}$ & 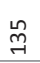 & : & 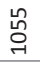 & ब్లి & $\stackrel{\text { I }}{్}$ & ڤn \\
\hline & $\begin{array}{r}\text { әz!S } \\
\text { ue!pəuس }\end{array}$ & 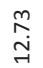 & $\begin{array}{l}\text { 우 } \\
\text { ㄱ } \\
\rightarrow\end{array}$ & $\begin{array}{l}\text { 우 } \\
\text { 북 }\end{array}$ & $\underset{\substack{m \\
r}}{m}$ & $\begin{array}{l}\stackrel{n}{m} \\
\stackrel{\sim}{J}\end{array}$ & 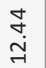 & $\begin{array}{l}\text { nू } \\
\text { فำ }\end{array}$ & $\begin{array}{l}\stackrel{0}{0} \\
\dot{J}\end{array}$ & 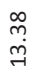 & $\underset{\sim}{\infty}$ & 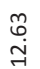 & $\begin{array}{l}m \\
0 \\
\dot{\varphi}\end{array}$ & $\begin{array}{l}\ddot{0} \\
\ddot{n}\end{array}$ & 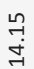 \\
\hline & $\begin{array}{r}\text { yd } \forall \text { J } \\
\text { ue!poum }\end{array}$ & $\begin{array}{l}\dot{0} \\
\dot{0} \\
\dot{m}\end{array}$ & 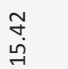 & $\begin{array}{l}\text { ᄋ } \\
\text { - }\end{array}$ & $\underset{\infty}{\infty}$ & $\begin{array}{l}\infty \\
\infty \\
\infty\end{array}$ & $\begin{array}{l}\stackrel{0}{n} \\
\infty\end{array}$ & ஸุ & 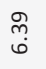 & $\stackrel{m}{n}$ & $\begin{array}{l}-1 \\
\stackrel{9}{9} \\
\text {. }\end{array}$ & 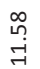 & ఫ্ণ & $\underset{\infty}{\stackrel{n}{\infty}}$ & $\begin{array}{l}\infty \\
\infty \\
\infty \\
\infty\end{array}$ \\
\hline & $7 \nabla$ ие!рәш & $\underset{7}{\stackrel{9}{7}}$ & $\underset{-}{\mathcal{H}}$ & $\stackrel{\infty}{\stackrel{\infty}{\rightarrow-1}}$ & $\underset{\sim}{\sim}$ & $\stackrel{n}{\sim}$ & 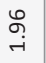 & 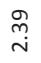 & $\underset{\sim}{\stackrel{\sim}{\sim}}$ & 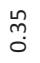 & 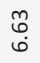 & 年 & $\stackrel{\circ}{\text { ஸn }}$ & 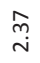 & $\stackrel{g}{\text { g }}$ \\
\hline & $\begin{array}{r}\text { IdgllyOyd } \\
\text { ue!pəu }\end{array}$ & $\stackrel{0}{\stackrel{r}{r}}$ & $\stackrel{f}{\text { f }}$ & $\stackrel{m}{\rightarrow}$ & $\stackrel{\text { Ț }}{\text { i }}$ & 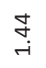 & 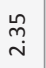 & $\underset{\mathrm{f}}{\mathrm{f}}$ & $\begin{array}{l}\text { ô } \\
\text { ó }\end{array}$ & $\underset{\text { i }}{\tilde{N}}$ & $\stackrel{n}{n}$ & $\stackrel{\text { L }}{\text { L }}$ & ने & $\stackrel{m}{m}$ & హ్ \\
\hline & d77 ue!pәшu & $\stackrel{\infty}{\sim}$ & $\stackrel{m}{m}$ & $\begin{array}{l}\infty \\
0 \\
0\end{array}$ & \& & ঢ! & $\begin{array}{l}\vec{b} \\
0 \\
0\end{array}$ & : & $\underset{n}{\tilde{N}}$ & 苞 & 움 & न1 & ֻึ̊? & 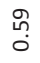 & ఫ़ \\
\hline & & 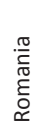 & 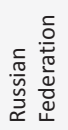 & 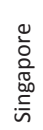 & 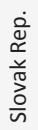 & $\begin{array}{l}\frac{0}{\frac{\pi}{\bar{N}}} \\
\frac{\partial}{\omega}\end{array}$ & 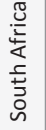 & 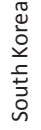 & $\begin{array}{l}\frac{5}{\pi} \\
\text { ñ } \\
\text { ñ }\end{array}$ & 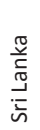 & $\begin{array}{l}\text { dै } \\
\sum_{0}^{0} \\
\text { un }\end{array}$ & 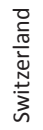 & 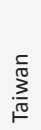 & 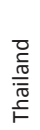 & : \\
\hline
\end{tabular}




\begin{tabular}{|c|c|c|c|c|c|c|c|c|c|}
\hline 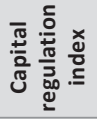 & פᄏyd כ כ & 욱 & $\sigma$ & $\sigma$ & $m$ & $\infty$ & $\infty$ & $\sigma$ & $\sigma$ \\
\hline 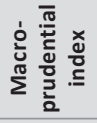 & уэмоууоя & $\stackrel{0}{0}$ & 0 & 0 & $\circ$ & $\circ$ & $\stackrel{\text { வீं }}{\check{c}}$ & $\stackrel{\oplus}{\check{c}}$ & $\stackrel{\ddot{ர}}{\check{c}}$ \\
\hline \multirow{7}{*}{ 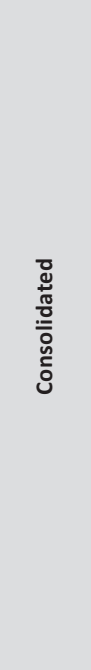 } & syueq \# & $\vec{\sim}$ & $m$ & ำ & $\stackrel{m}{m}$ & $\stackrel{\varphi}{\llcorner}$ & $\circ$ & เn & $\circ$ \\
\hline & м.əsqo \# & 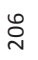 & $\stackrel{\sim}{\sim}$ & $\underset{ন}{\stackrel{-}{G}}$ & 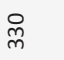 & I্ & $\circ$ & 유 & $\circ$ \\
\hline & $\begin{array}{r}\text { әz!S } \\
\text { uе!рәш }\end{array}$ & $\stackrel{m}{n}$ & ने & $\begin{array}{l}\hat{0} \\
\text { b. }\end{array}$ & $\underset{\sim}{\sim}$ & $\stackrel{m}{m}$ & & $\begin{array}{l}\underset{n}{n} \\
\dot{\varphi}\end{array}$ & \\
\hline & 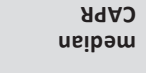 & $\begin{array}{l}\stackrel{\forall}{g} \\
\stackrel{G}{\neg}\end{array}$ & $\stackrel{m}{\stackrel{m}{\sim}}$ & ֻْ & ঠே & $\begin{array}{l}\stackrel{\infty}{+} \\
\sigma\end{array}$ & & $\begin{array}{l}\infty \\
\infty \\
0 \\
0\end{array}$ & \\
\hline & $1 \nabla$ uе!рәш & $\begin{array}{l}\text { बे } \\
\text { ஸू }\end{array}$ & $\stackrel{\vec{m}}{\ddot{N}}$ & $\begin{array}{l}\dot{U} \\
\dot{m}\end{array}$ & $\begin{array}{l}\text { ஞ் } \\
\text { ஸ் }\end{array}$ & $\stackrel{\oplus}{m}$ & & 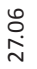 & \\
\hline & $\begin{array}{r}\text { Idgllfoyd } \\
\text { ue!pou }\end{array}$ & $\hat{o}$ & शे & $\begin{array}{l}\stackrel{\varphi}{\tilde{n}} \\
\dot{m}\end{array}$ & 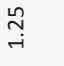 & 邑 & & 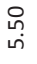 & \\
\hline & d77 ue!pәш & $\begin{array}{l}0 \\
\stackrel{0}{0} \\
0\end{array}$ & $\stackrel{-1}{0}$ & Ф్ & શิ & $\stackrel{n}{0}$ & & $\begin{array}{l}\infty \\
0 \\
0\end{array}$ & \\
\hline \multirow{7}{*}{ 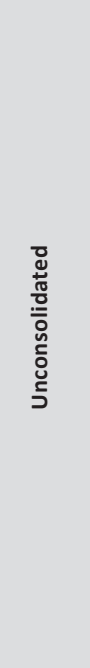 } & syueq \# & $\infty$ & 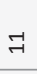 & $\stackrel{\Perp}{\sim}$ & ○ & ํํํ & $\stackrel{\infty}{\sim}$ & $\stackrel{\sim}{\sim}$ & in \\
\hline & sqo \# & $\mathbb{N}$ & 국 & $\stackrel{\infty}{\sim}$ & นู & $\frac{?}{\hat{\imath}}$ & ન્ & $\stackrel{\infty}{\sim}$ & $\stackrel{m}{m}$ \\
\hline & $\begin{array}{r}\text { әz!S } \\
\text { ие!рәш }\end{array}$ & $\begin{array}{l}\stackrel{ }{न} \\
\text { ํํㄱ }\end{array}$ & $\begin{array}{l}\stackrel{m}{m} \\
\underset{-}{-}\end{array}$ & ָ̊n & $\begin{array}{l}\stackrel{+}{+} \\
\dot{+}\end{array}$ & $\begin{array}{l}\text { 음 } \\
\text { - } \\
\rightarrow\end{array}$ & 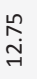 & 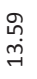 & $\begin{array}{l}\text { రి } \\
\text { ஸ் }\end{array}$ \\
\hline & $\begin{array}{r}\text { yd } \forall \text { } \\
\text { ue!pəuس }\end{array}$ & $\begin{array}{l}\text { શે } \\
\text { ન- }\end{array}$ & กิ & $\begin{array}{l}\mathscr{0} \\
\stackrel{6}{\sim} \\
\end{array}$ & ผn & $\begin{array}{l}\stackrel{n}{\kappa} \\
\text { ต் }\end{array}$ & $\begin{array}{l}-1 \\
\infty \\
\infty\end{array}$ & $\begin{array}{l}\stackrel{\infty}{\sim} \\
\stackrel{-}{\rightarrow}\end{array}$ & 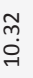 \\
\hline & $7 \nabla$ ue!pәш & ने & $\stackrel{\text { बे }}{\rightarrow}$ & 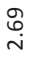 & ڤ̆ & $\stackrel{s}{-i}$ & $\begin{array}{l}-1 \\
0 \\
0\end{array}$ & $\stackrel{\sim}{m}$ & $\stackrel{\substack{++}}{+}$ \\
\hline & $\begin{array}{r}\text { Idgllyoyd } \\
\text { ue!pəu }\end{array}$ & $\begin{array}{l}\tilde{N} \\
\dot{m}\end{array}$ & $\begin{array}{l}\dot{\forall} \\
\dot{\sigma}\end{array}$ & $\underset{\sim}{\stackrel{0}{N}}$ & ન્' & $\begin{array}{l}\mathscr{q} \\
\stackrel{+}{-}\end{array}$ & 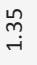 & $\begin{array}{l}\stackrel{\omega}{\infty} \\
\dot{m}\end{array}$ & $\stackrel{\infty}{\stackrel{\infty}{0}}$ \\
\hline & d7ר ue!pəu & $\begin{array}{l}\stackrel{\infty}{\infty} \\
\stackrel{\infty}{0}\end{array}$ & $\stackrel{\text { ษ }}{\circ}$ & $\stackrel{\infty}{\infty}$ & $\begin{array}{l}\infty \\
\circ \\
\circ\end{array}$ & 굼 & تี & $\stackrel{\infty}{\infty}$ & $\begin{array}{l}\text { g) } \\
-1\end{array}$ \\
\hline \multicolumn{2}{|r|}{ 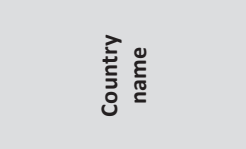 } & 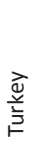 & 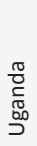 & 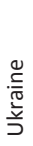 & 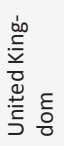 & 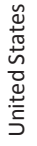 & 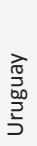 & $\begin{array}{l}\frac{\pi}{0} \\
\frac{N}{N} \\
\frac{0}{0} \\
\frac{D}{N}\end{array}$ & 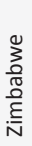 \\
\hline
\end{tabular}

में के

苗.

的雪 으 펗 임

สี 흥ำ

요료

글을

马 웡 ᅯ

茂的

닥율

的芯艺

- 节焉 I

$\exists$ is $\&$ 드응 증 을 흘 ปব

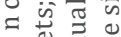
क ज (1) $\pi$ \% 잉 $\approx$ ब $>$ 光

$\circ$ 号卉

⿰ 幺 त $\because$ 펑 드를 呦些 के - วดी $\therefore$ こ 유 ㄷㄴㄴㅇㅛ บै 1 is ठ О $\therefore$ हैं के 元的*

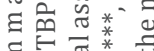
घี

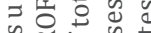
๑) 㟔过 ᄃ is 政 $+\pi \pi_{0}^{\circ}$

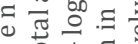
क

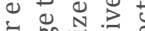
ล (1) के एँ - 0 is के $\pi)^{\circ} \pi$ us

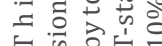


Table A2. Descriptive statistics and correlations in the full sample (Panel B) in unconsolidated and consolidated data

\begin{tabular}{|c|c|c|c|c|c|c|c|}
\hline & LLP & PROFITBPT & $\Delta \mathrm{L}$ & CAPR & Size & GDPG & Unempl \\
\hline & \multicolumn{7}{|c|}{ Descriptive statistics } \\
\hline & \multicolumn{7}{|c|}{ Unconsolidated } \\
\hline mean & 0.496 & 1.585 & 3.353 & 11.115 & 12.265 & 1.542 & 6.593 \\
\hline median & 0.214 & 1.457 & 1.233 & 9.750 & 11.908 & 1.681 & 5.900 \\
\hline sd & 1.247 & 3.545 & 13.232 & 5.685 & 1.872 & 2.819 & 2.473 \\
\hline $\min$ & -18.902 & -254.546 & -49.857 & 0.005 & 3.745 & -17.952 & 0.700 \\
\hline $\max$ & 49.670 & 315.416 & 199.473 & 50.000 & 21.855 & 30.344 & 27.200 \\
\hline \multirow[t]{2}{*}{ \# obs } & 82356 & 93731 & 91789 & 93121 & 94388 & 109968 & 109968 \\
\hline & \multicolumn{7}{|c|}{ Consolidated } \\
\hline mean & 0.730 & 2.029 & 13.822 & 9.297 & 6.802 & 2.481 & 7.363 \\
\hline median & 0.377 & 1.555 & 6.479 & 7.814 & 6.803 & 2.180 & 6.750 \\
\hline sd & 1.298 & 2.368 & 35.711 & 5.911 & 0.920 & 3.689 & 3.648 \\
\hline $\min$ & -9.634 & -9.068 & -53.133 & 0.078 & 3.892 & -16.589 & 0.700 \\
\hline $\max$ & 19.654 & 40.153 & 884.389 & 49.468 & 9.486 & 30.344 & 27.200 \\
\hline \multirow[t]{3}{*}{ \# obs } & 9454 & 9668 & 8951 & 9968 & 10080 & 11892 & 11892 \\
\hline & \multicolumn{7}{|c|}{ Correlations } \\
\hline & \multicolumn{7}{|c|}{ Unconsolidated } \\
\hline LLP & 1 & & & & & & \\
\hline PROFITBPT & $0.177^{* * *}$ & 1 & & & & & \\
\hline$\Delta \mathrm{L}$ & $-0.045^{* * *}$ & $-0.030 * * *$ & 1 & & & & \\
\hline CAPR & $0.087^{* * *}$ & $0.157^{* * *}$ & $0.113^{* * *}$ & 1 & & & \\
\hline Size & $0.008^{* * *}$ & $-0.020 * * *$ & $0.052^{* * *}$ & $-0.324 * * *$ & 1 & & \\
\hline GDPG & $-0.081^{* * *}$ & $0.018 * * *$ & 0.000 & $0.041^{* * *}$ & $-0.007 * * *$ & 1 & \\
\hline \multirow[t]{2}{*}{ Unempl } & $0.126 * * *$ & -0.002 & $-0.013^{* * *}$ & 0.000 & $0.121 * * *$ & $-0.087 * * *$ & 1 \\
\hline & \multicolumn{7}{|c|}{ Consolidated } \\
\hline LLP & 1 & & & & & & \\
\hline PROFITBPT & $0.339 * * *$ & 1 & & & & & \\
\hline$\Delta \mathrm{L}$ & -0.004 & $0.172 * * *$ & 1 & & & & \\
\hline
\end{tabular}


Table A2. Descriptive statistics...

\begin{tabular}{|c|c|c|c|c|c|c|c|}
\hline & LLP & PROFITBPT & $\Delta \mathrm{L}$ & CAPR & Size & GDPG & Unempl \\
\hline & \multicolumn{7}{|c|}{ Descriptive statistics } \\
\hline & \multicolumn{7}{|c|}{ Unconsolidated } \\
\hline CAPR & $0.170 * * *$ & $0.421 * * *$ & $0.096 * * *$ & 1 & & & \\
\hline Size & $-0.150 * * *$ & $-0.253^{* * *}$ & $-0.134 * * *$ & $-0.528 * * *$ & 1 & & \\
\hline GDPG & $-0.133 * * *$ & $0.142 * * *$ & $0.253^{* * *}$ & $0.108 * * *$ & $-0.133 * * *$ & 1 & \\
\hline Unempl & $0.140 * * *$ & $0.135^{* * *}$ & $0.034 * * *$ & $0.175 * * *$ & $-0.217^{* * *}$ & $-0.040 * * *$ & 1 \\
\hline
\end{tabular}

This table presents the summary descriptive statistics of variables included in the study: LLP - loan loss provisions over average total assets; PROFITBPT profit before provisions and taxes over average assets; $\triangle \mathrm{L}$ - loans growth; $C A P R$ - equity capital divided by total assets; size - logarithm of total assets; GDPG - real GDP growth per capita; Unempl - annual unemployment rate; obs - denotes observations; \#-denotes the number of.

S o u r c e : authors' calculations. 